FIU Law Review

Fall 2015

\title{
Bob Jonesing: Same-Sex Marriage and the Hankering to Strip Religious Institutions of Their Tax-Exempt Status
}

Timothy J. Tracey

Ave Maria School of Law

Follow this and additional works at: https://ecollections.law.fiu.edu/lawreview

Part of the Other Law Commons

Online ISSN: 2643-7759

\section{Recommended Citation}

Timothy J. Tracey, Bob Jonesing: Same-Sex Marriage and the Hankering to Strip Religious Institutions of Their Tax-Exempt Status, 11 FIU L. Rev. 85 (2015).

DOI: https://dx.doi.org/10.25148/lawrev.11.1.9

This Article is brought to you for free and open access by eCollections. It has been accepted for inclusion in FIU Law Review by an authorized editor of eCollections. For more information, please contact lisdavis@fiu.edu. 


\title{
Bob Jonesing: Same-Sex Marriage and the Hankering to Strip Religious Institutions of Their Tax-Exempt Status
}

\author{
Timothy J. Tracey*
}

\section{INTRODUCTION}

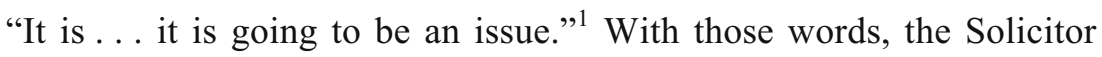
General of the United States, Donald B. Verrilli, Jr., announced that religious liberty is directly threatened by the legalization of same-sex marriage. General Verrilli represented the Obama Administration at the oral argument in Obergefell $v$. Hodges, ${ }^{2}$ the case concerning whether the Fourteenth Amendment guarantees the right of same-sex couples to marry. He made the statement in response to a question from Justice Samuel Alito.

JUSTICE ALITO: Well, in the Bob Jones case, the Court held that a college was not entitled to tax-exempt status if it opposed interracial marriage or interracial dating. So would the same apply to a university or a college if it opposed same-sex marriage?

GENERAL VERRILLI: You know, I . . . I don't think I can answer that question without knowing more specifics, but it's certainly going to be an issue. I . . I don't deny that. I don't deny that, Justice Alito. It is ... it is going to be an issue. ${ }^{3}$

In Bob Jones University v. United States, ${ }^{4}$ the United States Supreme Court held that the Internal Revenue Service (IRS) could revoke the taxexempt status of two private, religious schools-Goldsboro Christian Schools, Inc. and Bob Jones University-because their admission policies were "contrary to a fundamental public policy." Goldsboro flatly denied admission to black students, while Bob Jones admitted black students but prohibited interracial dating. ${ }^{6}$ Both schools genuinely believed that the

Associate Professor of Law, Ave Maria School of Law. My thanks to Tricia, Nathan, and Noah for their love, support, and encouragement. SDG.

1 Transcript of Oral Argument at 38, Obergefell v. Hodges, 135 S. Ct. 2584 (2015) (Nos. 14-556, $14-562,14-571,14-574)$.

2135 S. Ct. 2584, 2591 (2015).

3 Transcript of Oral Argument, supra note 1, at 38.

4461 U.S. 574 (1983).

$5 \quad I d$. at 592-93.

6 See id. at $580,583$. 
Bible prohibited racial intermixing. ${ }^{7}$

The schools argued that, as religious institutions whose discrimination was religiously required, they should be exempt from the IRS policy of conditioning tax-exempt status for educational institutions on compliance with anti-discrimination norms. The Court rejected the argument that the denial violated the schools' free exercise rights. The Court ruled that eradicating race discrimination was an interest "so compelling as to allow even regulations prohibiting religiously based conduct." " The Court acknowledged that the "[d]enial of tax benefits will inevitably have a substantial impact on the operation of private religious schools," but "[t]hat [the] governmental interest [in eliminating discrimination] substantially outweigh[ed] whatever burden denial of tax benefits place[d] on petitioners' exercise of their religious beliefs."

If opposition to same-sex marriage is also "contrary to a fundamental public policy," then what happens to the private, religious schools that prohibit same-sex dating or deny housing to students in same-sex relationships? After all, opposition to same-sex marriage, according to the Obergefell majority, "disparage[s] [same-sex couples'] choices,"10 "diminish[es] their personhood,"11 and "demeans or stigmatizes"12 them. Surely, that too runs "contrary to fundamental public policy?",

Writing for the majority, Justice Kennedy did little to answer that concern.

Finally, it must be emphasized that religions, and those who adhere to religious doctrines, may continue to advocate with utmost, sincere conviction that, by divine precepts, same-sex marriage should not be condoned. The First Amendment ensures that religious organizations and persons are given proper protection as they seek to teach the principles that are so fulfilling and so central to their lives and faiths, and to their own deep aspirations to continue the family structure they have long revered. ${ }^{14}$

True, it is a nod and a smile in the direction of the First Amendment. But it is little more. The promise that people of faith may "advocate" and "teach" their beliefs about marriage gives scant assurance that they can in fact act

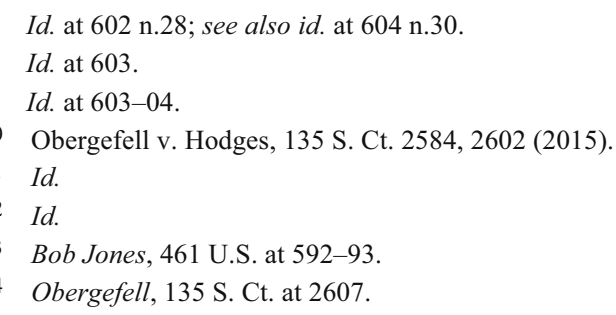


on those beliefs. A church can teach that marriage is between one man and one woman but can the church refuse to perform a same-sex marriage? A Christian college can advocate for the complementary roles of husbands and wives in marriage but can they establish rules prohibiting same-sex relationships? The dissenting Justices harped on this anemic view of religious liberty posited by the majority. Chief Justice Roberts wrote:

The majority graciously suggests that religious believers may continue to "advocate" and "teach" their views of marriage. The First Amendment guarantees, however, the freedom to "exercise" religion. Ominously, that is not a word the majority uses.

Hard questions arise when people of faith exercise religion in ways that may be seen to conflict with the new to same-sex marriagewhen, for example, a religious college provides married student housing only to opposite-sex married couples, or a religious adoption agency declines to place children with same-sex married couples... Unfortunately, people of faith can take no comfort in the treatment they receive from the majority today. ${ }^{15}$

Justice Thomas expressed similar concerns:

In our society, marriage is not simply a governmental institution; it is a religious institution as well. Today's decision might change the former, but it cannot change the latter. It appears all but inevitable that the two will come into conflict, particularly as individuals and churches are confronted with demands to participate in and endorse civil marriages between same-sex couples.

The majority appears unmoved by that inevitability. It makes only a weak gesture toward religious liberty in a single paragraph. And even that gesture indicates a misunderstanding of religious liberty in our Nation's tradition. Religious liberty is about more than just the protection for "religious organizations and persons ... as they seek to teach the principles that are so fulfilling and so central to their lives and faiths." Religious liberty is about freedom of action in matters of religion generally, and the scope of that liberty is directly correlated to the civil restraints placed upon religious practice.

Although our Constitution provides some protection against such governmental restrictions on religious practices, the People have long elected to afford broader protections than this Court's constitutional precedents mandate. Had the majority allowed the definition of marriage to be left to the political process-as the Constitution 
requires - the People could have considered the religious liberty implications of deviating from the traditional definition as part of their deliberative process. Instead, the majority's decision short-circuits that process, with potentially ruinous consequences for religious liberty. ${ }^{16}$ Justice Alito said similarly:

Perhaps recognizing how its reasoning may be used, the majority attempts, toward the end of its opinion, to reassure those who oppose same-sex marriage that their rights of conscience will be protected. We will soon see whether this proves to be true. I assume that those who cling to old beliefs will be able to whisper their thoughts in the recesses of their homes, but if they repeat those views in public, they will risk being labeled as bigots and treated as such by governments, employers, and schools. ${ }^{17}$

As if on cue, only two days after the Court handed down Obergefell, Mark Oppenheimer, a news columnist, took to the Time magazine blog to call for the IRS to strip religious organizations of their tax-exempt status. Invoking Bob Jones, he said, "It's time to abolish, or greatly diminish, their tax-exempt statuses." He concluded, "So yes, the logic of gay-marriage rights could lead to a reexamination of conservative churches' tax exemptions .... But when that day comes, it will be long overdue." 18

Oppenheimer knows the consequences of shucking religious organizations of their tax-exempt status would be disastrous. He conceded that "charitable giving would drop," and that "churches would be squeezed out of high-property-value areas." 19 And the poor be damned-"we'd have fewer church soup kitchens." ${ }^{20}$ Professor Denny Burk gave the grisly details:

When tax exemptions are removed, donors will give far less than they are giving now. Churches will become liable to property taxes. That means that many churches will have to forfeit their property to the government because they won't be able to afford the taxes they have to pay on it. Many of them wouldn't be able to pay them now. If donations went down, they would be that much further from being able to pay them. As a result, churches that reside on valuable properties in

16 Id. at 2638-39 (Thomas, J., dissenting).

17 Id. at 2642-43 (Alito, J., dissenting).

18 Mark Oppenheimer, Now's the Time to End Tax Exemptions for Religious Institutions, TIME (June 28, 2015), http://time.com/3939143/nows-the-time-to-end-tax-exemptions-for-religious-institu tions.

$\begin{array}{ll}19 & I d \\ 20 & I d\end{array}$


urban locations would be immediately vulnerable. Eventually, so would everyone else. A call for ending tax exemptions for religious institutions is a call to close them down .... ${ }^{21}$

Oppenheimer is confused. He misunderstands the nature of tax exemptions for religious organizations. Throughout his blog post, he called for the government to stop "subsidizing" religion. ${ }^{22}$ But when the federal government exempts religious groups from paying federal income tax, it is not choosing to bankroll religion. Rather, the government is recognizing that the Establishment Clause of the First Amendment mandates a separation of church and state. The Clause acts as a restraint on the federal government's power over matters "respecting an establishment of religion." ${ }^{23}$ It places these matters outside the purview of government power. ${ }^{24}$ The government refrains from taxation of religious organizations "to accommodate the autonomy of religious actors and activities." 25 Tax exemption, said Professor Edward Zelinsky, is an "acknowledgement of sectarian sovereignty, . . rather than the subsidization of religion." "In the final analysis, tax exemption," observed Zelinsky, "does not subsidize churches, but leaves them alone." 26

Every law student knows the one-liner from McCulloch v. Maryland ${ }^{27}$ : "the power to tax involves the power to destroy." 28 The U.S. Supreme Court held in $\mathrm{McC}$ Culloch that the principle of federalism - the structural restraint imposed by the Constitution on the federal government's power over the states and, vice-versa, the states' power over the federal governmentprevented the State of Maryland from taxing the federal bank. Were it otherwise, the Court said, the state could tax the federal bank out of existence. That would invert the structure of the Constitution, which makes the federal government supreme over the states. Federalism-the very structure of government enshrined in the Constitution-placed the power to tax the instruments of the federal government outside the purview of the

21 Denny Burk, Ending Tax Exemptions Means Ending Churches, THE FeDERALIST (June 29, 2015), http://thefederalist.com/2015/06/29/ending-tax-exemptions-means-ending-churches.

22 Oppenheimer, supra note 18.

23 U.S. CONST. amend. I.

24 See Carl H. Esbeck, The Establishment Clause as a Structural Restraint on Governmental Power, 84 IowA L. REV. 1, 2 (1998) (arguing that the Establishment Clause is "properly understood as a structural restraint on governmental power" and "its task is to negate from the purview of civil governance all matters 'respecting an establishment of religion"').

25 Edward A. Zelinsky, Are Tax “Benefits” for Religious Institutions Constitutionally Dependent on Benefits for Secular Entities?, 42 B.C. L. REV. 805, 807 (2001).

26 Id.

2717 U.S. 316 (1819).

28 Id. at 431. 
states. $^{29}$

In the same way, the Establishment Clause places outside the purview of the federal government matters "respecting an establishment of religion,"30 including the power to tax religious organizations. Just as federalism recognizes the federal government and the states as distinct sovereigns with separate spheres of power, the Establishment Clause recognizes the church and the civil government as separate and distinct sovereigns. ${ }^{31}$ Neither can encroach on the territory of the other. Were the federal government permitted to tax religious organizations, it could snuff religion out.

The IRS's own regulations recognize this limitation. Churches "are automatically considered tax exempt and are not required to apply for and obtain recognition of tax-exempt status from the IRS." 32 The Constitution itself precludes the government from taxing churches. It is automatic. The reason religious organizations, other than churches, must apply for taxexempt status is to ensure that they are in fact religious. Once that determination is made, they too are exempt from federal income tax. ${ }^{33}$ The IRS is merely recognizing what the Constitution already mandates.

The Bob Jones case represents the lone exception. Eradicating race discrimination is the only "fundamental public policy" the U.S. Supreme Court has held overrides the First Amendment mandate of separation of church and state. The IRS agrees. "Currently the sole basis for revocation of exemption on public policy grounds," says the IRS, "is engaging in race discrimination." 34 The government's interest in "eradicating racial discrimination in education" is, according to the Bob Jones court, "so compelling" as to warrant the breach of the wall of separation. ${ }^{35}$

Bob Jones, in this regard, is singular. It is a historical anomaly. "[The case]," said Professor Olatunde Johnson, "is too extraordinary to matter much." "36 Private, segregated schools had sprung up across the South as a

29 See id. at $428-35$.

30 U.S. CONST. amend. I.

31 See Evelyn Brody, Of Sovereignty and Subsidy: Conceptualizing the Charity Tax Exemption, 23 J. CORP. L. 585 (1998) (conceptualizing exemption under Section 501(c)(3) as premised on the notion that charitable entities are "co-sovereigns" with the state).

32 INTERNAL REVENUE SERVICE, TAX GUIDE FOR CHURCHES \& RELIGIOUS ORGANIZATIONS 2, www.irs.gov/pub/irs-pdf/p1828.pdf (last visited Sept. 9, 2015).

33 See id. at 3

34 Internal Revenue Service, Field Service Advice Memorandum, 1997 FSA LEXIS 478, at*11 (Apr. 23, 1997).

35 Bob Jones Univ. v. United States, 461 U.S. 574, 603-04 (1983).

36 Olati Johnson, The Story of Bob Jones University v. United States: Race, Religion, and Congress' Extraordinary Acquiescence 29 (Colum. Pub. L. \& Legal Theory Working Papers, Paper No. 9184, 2010), http://lsr.nellco.org/columbia_pllt/9184. 
way to dodge integrated public education. States were fostering the expansion of these schools, according to Johnson, by "enacting legislation mandating or allowing the closing of public schools to resist desegregation or providing state tax credits and tuition grants to students attending private schools." ${ }^{37}$ Denying tax-exempt status was the only way to curb the growth of these schools. Moreover, "the position of all three branches of the Federal Government was unmistakably clear"-racial discrimination in education "violates deeply and widely accepted views of elementary justice." $" 38$

Bob Jones, thus, sits alongside the myriad of other court decisions from the civil rights era where the Supreme Court was willing to go to extraordinary lengths to eradicate race discrimination. Cases, like Norwood v. Harrison ${ }^{39}$ where the Court deviated from the norm to get at the horrible evil that is race discrimination. In Norwood, the Court held that the racial discrimination of private schools in Mississippi could be attributed to the state, because the state provided the schools with free textbooks. ${ }^{40}$ Yet the general rule is, even if the state is providing 99 percent of the funding for a private organization and heavily regulating almost every aspect of its operation, the private organization is nonetheless not a state actor. ${ }^{41}$ The Court was willing to set aside this general rule to go after racism. The Court did not vitiate the rule. Instead, it found that the extraordinary circumstances - the long history of slavery, racism, and discrimination against African-Americans - warranted setting the rule aside in this one instance.

Professor Michael Paulsen put it this way:

Bob Jones strikes me as sui generis - a just result that seemingly had to be reached because of our national commitment to racial equality and our shameful national history of slavery and segregation, but that ought not to have been reached at such expense to constitutional

\section{Id. at 4.}

38 Bob Jones, 461 U.S. at 592, 598.

39413 U.S. 455 (1973).

$40 \quad I d$. at 467 ("[T]he constitutional infirmity of the Mississippi textbook program is that it significantly aids the organization and continuation of a separate system of private schools which, under the District Court holding, may discriminate if they so desire.").

41 See Rendell-Baker v. Kohn, 457 U.S. 830, 832 (1982) ("In recent years, public funds have accounted for at least $90 \%$, and in one year 99\%, of respondent school's operating budget."); see also id. at 840 ("[W]e conclude that the school's receipt of public funds does not make the discharge decisions acts of the State.”); Blum v. Yaretsky, 457 U.S. 991, 1011 (1982) ("That programs undertaken by the State result in substantial funding of the activities of a private entity is no more persuasive than the fact of regulation of such an entity in demonstrating that the State is responsible for decisions made by the entity in the course of its business."). 
principle - and should be treated as such. It should not be permitted to generate consequences much beyond the facts of the particular case. ${ }^{42}$

Hence, Bob Jones cannot be generalized into a rule that the IRS can deny religious organizations tax-exempt status anytime something smells mildly of discrimination. Even the panoply of court decisions, legislation, and public policy pronouncements concerning gender discrimination have not added up to a "fundamental public policy" sufficient to deny religious organizations tax-exempt status. Churches and other religious organizations routinely discriminate on the basis of gender when it comes to ministers, priests, pastors, and the like. Yet they retain their tax-exempt status.

Prohibiting sexual orientation discrimination similarly cannot be called a "fundamental public policy" that warrants overriding the constitutional mandate of separation of church and state. At least not yet. Unlike the history that gave rise to Bob Jones, thousands of private schools did not spring up as a means to avoid attending school with gays and lesbians. In fact, many private schools actively recruit gay men and lesbians. ${ }^{43}$

Nor have "all three branches of the Federal Government" been "unmistakably clear" in condemning sexual orientation discrimination. ${ }^{44}$ Executive orders signed by Presidents Clinton and Obama prohibit sexual orientation discrimination by the federal government and its contractors. ${ }^{45}$ But federal law otherwise does not prohibit sexual orientation discrimination. Congress has repeatedly declined to pass the Employment

42 Michael Stokes Paulsen, A Funny Thing Happened on the Way to the Limited Public Forum: Unconstitutional Conditions on "Equal Access" for Religious Speakers and Groups, 29 U.C. DAVIS L. REV. 653, 694 (1996).

43 See John Schwartz, Finding a Gay-Friendly Campus, N.Y. TiMES (Apr. 16, 2010), www. nytimes.com/2010/04/18/education/edlife/18guidance-t.html?_r=0; Matt Lamb, Penn's Gaydar Admissions Project Goes Back Years: Gays are “Blue-Chip Recruits”, THE COLLEGE FIX (Nov. 20, 2014), www.thecollegefix.com/post/20203/; Scott Jaschik, The Same Boxes to Check, INSIDE HIGHER ED (Jan. 26, 2011), www.insidehighered.com/news/2011/01/26/common_application_rejects_new_questions_on sexual_orientation_and_gender_identity; Doree Shafrir, The Ivy League's Big Gay Admission, DETAILS (Sept. 23, 2010), www.details.com/culture-trends/news-and-politics/201009/gay-lgbt-sexual-orientationivy-league-admission.

44 Bob Jones Univ. v. United States, 461 U.S. 574, 598 (1983).

45 See Exec. Order No. 12,968, 60 Fed. Reg. 40245 (Aug. 2, 1995) (establishing criteria for the issuance of security clearances including sexual orientation for the first time in its non-discrimination language: "The United States Government does not discriminate on the basis of race, color, religion, sex, national origin, disability, or sexual orientation in granting access to classified information." It also said that "no inference" about suitability for access to classified information "may be raised solely on the basis of the sexual orientation of the employee."); Exec. Order No. 13,087, 63 Fed. Reg. 30097 (May 28,1998 ) (prohibiting discrimination based on sexual orientation in the competitive service of the federal civilian workforce); Exec. Order No. 13,672, 79 Fed. Reg. 42971 (July 21, 14) (adding "gender identity" to the categories protected against discrimination in hiring in the federal civilian workforce and both "sexual orientation" and "gender identity" to the categories protected against discrimination in hiring and employment on the part of federal government contractors and sub-contractors). 
Non-Discrimination Act (ENDA), which would ban discrimination on the basis of sexual orientation in employment nationwide. ENDA has been introduced in every Congress since 1994, but has yet to pass both houses. ${ }^{46}$ The version of ENDA that passed the Senate in November 2013 contained a broad religious exemption. Referring directly to the religious exemption in Title VII, it exempted from the prohibition on employment discrimination based on sexual orientation the same class of religious organizations that are exempt from the existing prohibition on religious discrimination in employment. ${ }^{47}$ The Supreme Court in Obergefell held that the fundamental right to marry protected by the Fourteenth Amendment includes the right of same-sex couples to marry. But the Court did not hold that sexual orientation is a suspect or quasi-suspect class. ${ }^{48}$ Federal law, thus, at least as it currently sits, provides no basis for concluding that a "fundamental public policy" of prohibiting sexual orientation discrimination exists. ${ }^{49}$

That of course could change. In mid-July of 2015, the Equal Employment Opportunity Commission (EEOC) interpreted Title VII of the 1964 Civil Rights Act to forbid sexual orientation discrimination on the job as a form of "sex" discrimination. ${ }^{50}$ The EEOC's views on the scope of the Title VII are merely persuasive, not binding, authority on the courts. But if the EEOC's ruling sticks, it will accomplish what Congress could not: establish a national policy of protecting gay men and lesbians from job discrimination. Even if that happens, it would still be difficult to argue "all three branches of the Federal Government" have been "unmistakably clear" ${ }^{, 51}$ in condemning sexual orientation discrimination. Congress will have remained silent. But it would indicate a clear move toward a national policy against sexual orientation discrimination. Perhaps four to five years from now, the calculus under Bob Jones will come out differently.

46 See Employment Non-Discrimination Act, WIKIPEDIA, http://en.wikipedia.org/wiki/Employ ment_Non-Discrimination_Act\#113th_Congress (last visited Sept. 9, 2015).

$\overline{4} 7$ See Employment Non-Discrimination Act of 2013, S. 815, 113th Cong. $\S 6$ (2013), www. congress.gov/113/bills/s815/BILLS-113s815rfh.pdf.

48 See Obergefell v. Hodges, 135 S. Ct. 2584, 2602-05 (2015).

49 Although not directly relevant under Bob Jones, state law tells much the same story. Twentyone states and the District of Columbia have passed laws prohibiting sexual orientation in employment in the public and private sectors. All of these laws contain religious exemptions. See Jerome Hunt, A State-By-STAte Examination OF NONDiscrimination LAWS AND POlicies, CTR. For Am. PROGRESS ACTION FUND 3-4 (2012), www.americanprogress.org/issues/lgbt/report/2012/06/11/11696/ a-state-by-state-examination-of-nondiscrimination-laws-and-policies.

50 See Complainant v. Foxx, EEOC Appeal No. 0120133080 (July 16, 2015), www. americanbar.org/content/dam/aba/administrative/sexual_orientation/eeoc-lgbt-title-vii-decision.authch eckdam.pdf.

51 Bob Jones Univ. v. United States, 461 U.S. 574, 598 (1983). 
This Article argues that the income tax exemptions provided to religious institutions are constitutionally mandated and that whatever interest the government has in eradicating sexual orientation discrimination does not justify setting this mandate aside. Part I defines what is meant by "tax-exempt status." Part II shows that the religious exemption from the federal income tax is constitutionally required. The exemption is compelled by the structure of the U.S. Constitution, rather than a matter of government altruism. Part III lays out the extraordinary character of the Bob Jones case and its limited application beyond the eradication of race discrimination at educational institutions. Part IV argues that Bob Jones cannot be used to justify stripping religious institutions of their federal tax-exempt status. This Article concludes that the religious exemption from the income tax is about obeying the constitutional command to leave religious institutions alone and nothing in Bob Jones and Obergefell gives cause to do otherwise.

\section{What Do We MEAn BY “TAX-EXEMPt Status”?}

The Bob Jones court considered only whether the federal government, $v i s-a ̀-v i s$ the IRS, could deny private religious schools exemptions from federal income taxes, not exemptions from the slew of other taxes imposed on private religious schools, like payroll taxes. That is because the taxexempt designations doled out by the IRS spare a religious school from paying federal corporate income tax and nothing else. The IRS has no authority to exempt religious schools from other taxes.

Section 501(c) of the Internal Revenue Code provides a list of 29 nonprofit organizations that are exempt from federal income tax. ${ }^{52}$ The most common type of tax-exempt organization falls under the category 501(c)(3), which exempts organizations established for a variety of charitable purposes, including religious and educational purposes. ${ }^{53}$

To qualify for tax-exempt status, an organization must meet the following requirements:

- the organization must be organized and operated exclusively for religious, educational, scientific, or other

52 People often confuse the terms "nonprofit" and "tax exempt." Just because an organization is a nonprofit corporation does not make it tax exempt. Nonprofit status refers to incorporation status under state law; tax-exempt status refers to federal income tax exemption under the Internal Revenue Code. Nonprofit corporations, contrary to what the name suggests, can earn a profit, meaning they can generate more income than expenses. What they cannot do is distribute these earnings to individuals who control the organizations. They have no shareholders. Nonprofits exist to benefit the public good, not private investors. All profits must be reinvested into the nonprofit to further the purposes for which they were organized. Although many nonprofit corporations are also tax exempt, they are not automatically so. The nonprofit corporation must meet certain criteria and, generally, apply to the IRS.

53 See 26 U.S.C. $\S 501$ (c) (2015). 
charitable purposes,

- net earnings may not inure to the benefit of any private individual or shareholder,

- no substantial part of its activity may be attempting to influence legislation,

- the organization may not intervene in political campaigns, and

- the organization's purposes and activities may not be illegal or violate fundamental public policy. ${ }^{54}$

Private religious schools ordinarily satisfy these requirements. They are organized for religious and educational purposes, two of the permissible purposes spelled out in Section 501(c)(3). The schools are organized as nonprofit corporations, meaning they do not distribute earnings to investors or other private individuals. Rather, they reinvest their earnings into the school to further their religious and educational missions. The schools refrain from political activity, either lobbying or campaigning. And their purposes and activities are not illegal. The open question, of course, is whether their purposes and activities violate "fundamental public policy." But given that eradicating race discrimination in education is, thus far, the only public policy ground the IRS or the U.S. Supreme Court has recognized as sufficient to deny tax-exempt status, the bulk of private religious schools seem to be in compliance.

Private schools gain two perks from tax-exempt status. First, the tax exemption frees them from paying federal corporate income tax on their earnings. ${ }^{55}$ The caveat is that the income must be related to their religious and educational missions. Unrelated business income is still subject to taxation. ${ }^{56}$ Consider an example. A private Christian college opens a pizza parlor on campus to sell pizza to students and non-students alike. The college is a tax-exempt organization and its pizza parlor generates unrelated business income. While the tuition and fees generated by the college are tax exempt, its income from the pizza parlor is not. The pizza parlor is unrelated to the college's educational and religious purposes.

Second, tax-exempt status means contributions to private religious schools are tax deductible. ${ }^{57}$ Donors may deduct the amount donated to a private religious school from their taxable income and lower their tax bill. Obviously, that makes giving to private religious schools, or any other tax-

54 See id. § 501(c)(3); see also InTERnAL REVEnuE SERV., TAX Guide FOR CHuRChes \& RELIGIOUS ORGANIZATIONS 2 (2015), www.irs.gov/pub/irs-pdf/p1828.pdf.

55 See 26 U.S.C. $\$ 501$ (a) (2015).

56 See id. $\S 501(\mathrm{~b})$.

$57 \quad$ See id. $\$ 170$. 
exempt charity for that matter, more appealing than it would otherwise be.

But 501(c)(3) status does not give private schools a free ride. The schools are still on the hook for payroll and withholding taxes, unemployment taxes, property taxes, state and local income taxes, and sales tax. Moreover, as explained above, any income unrelated to the religious and/or educational purpose of the schools remains subject to federal income tax. Of course, state law could separately exempt religious schools from state and local taxes. But that is purely a function of state law and not the tax-exempt designation from the IRS.

\section{THE RELIGIOUS TAX EXEMPTION FROM THE}

\section{FEDERAL INCOME TAX IS CONSTITUTIONALLY REQUIRED} BY THE SEPARATION OF CHURCH AND STATE

The governing case law, the history, and the underlying policy considerations, all favor the conclusion that the exemption of religious organizations from the federal income tax is compelled by the Establishment Clause of the First Amendment.

\section{A. Is Tax-Exempt Status a Government Subsidy?}

Despite the heated rhetoric surrounding Obergefell, whether private religious schools opposing same-sex marriage may retain their tax-exempt status largely turns on a prosaic issue: is tax-exempt status of religious organizations a government subsidy or a constitutionally-mandated accommodation of religious exercise? If it is a subsidy, then tax exemption is a matter of government largess. Religious organizations have no right to an exemption. The government can choose to exempt private religious schools or not. But if tax-exempt status for religious organizations is commanded by the constitution, then the federal government has no choice in the matter. It must exempt religious organizations from federal income taxes. It cannot override that constitutional command absent the most extraordinary circumstances.

At first blush, the question seems daft. Of course, tax exemptions are subsidies. A subsidy is any "pecuniary aid furnished by a government to a private industrial undertaking, a charity organization, or the like." ${ }^{58}$ When the IRS exempts religious organizations from paying income tax, it undeniably provides them with "pecuniary aid." Less tax paid, means more money in the coffers. Obviously, right?

58 Subsidy, DiCTIONARY.COM, http://dictionary.reference.com/browse/subsidy (last visited Sept. 9, 2015) 
But that oversimplifies the matter. When used by the Supreme Court, the word "subsidy" is a term of art. The Court is not using the word according to its plain meaning. Otherwise, any time the government handed out money to a private entity, it could be dubbed a "subsidy." Rather, the Court uses the term to describe those particular instances where the government furnishes money to private entities to promote the government's own policies. ${ }^{59}$ In these instances, the government may take steps to ensure that the entities receiving subsidies fulfill the government's own policy objectives. And the government has no obligation, constitutional or otherwise, to subsidize entities that cannot or will not promote its policies. ${ }^{60}$

Suppose the University of Virginia (UVA), a public university, gives money to the organization Courage to Care to have Dr. Carolyn Cornelison address students about responsible drinking. ${ }^{61}$ UVA has an "Alcohol and Drug Policy" that provides, "The University... does not condone the illegal or otherwise irresponsible use of alcohol and other drugs." ${ }^{, 62}$ When UVA gives money to Courage to Care, it is doing so to promote its own policy concerning alcohol abuse. UVA is paying Dr. Cornelison to convey the university's own message. That money is properly termed a government subsidy. It is UVA furnishing money to a private entity to further its own policies.

Because the money is a subsidy, UVA has "latitude ... for restrictions on speech." ${ }^{63}$ The university "may take legitimate and appropriate steps to ensure that its message is neither garbled nor distorted by the grantee" without running afoul of the Constitution. ${ }^{64}$ It can tell Dr. Cornelison that she must speak about responsible drinking. It can prohibit her from using the money to stand up and talk about some other topic, like the academic challenges of getting a $\mathrm{PhD}$, without violating Dr. Cornelison's free speech rights. The Court put it this way: "[W]e have permitted the government to regulate the content of what is or is not expressed ... when it enlists private entities to convey its own message." ${ }^{, 65}$

59 See Legal Serv. Corp. v. Velazquez, 531 U.S. 533, 540-42 (2001); Rosenberger v. Rector \& Visitors of Univ. of Va., 515 U.S. 819, 833 (1995); Bd. of Regents of the Univ. of Wis. v. Southworth, 529 U.S. 217, 229, 235 (2000).

60 See Velazquez, 531 U.S. at 541; Rosenberger, 515 U.S. at 833; Southworth, 519 U.S. at 235.

61 See COURAGE TO CARE, www.ccspeaks.com (last visited Sept. 9 2015).

62 Alcohol and Drug Policy, Univ. of VA. Graduate ReC. ch. 4 (1998), www.virginia.edu/ registrar/records/98gradrec/chapter4/gchap4-2.3.html.

63 Velazquez, 531 U.S. at 541.

64 Rosenberger, 515 U.S. at 833.

$65 I d$. 
Moreover, UVA can subsidize speech about responsible drinking without needing to fund speech promoting the opposite viewpoint-speech extolling the "virtues" of frat parties. "[V]iewpoint-based funding decisions," said the Court, "can be sustained in instances ... in which the government used private speakers to transmit specific information pertaining to its own program." ${ }^{66}$ While such viewpoint is ordinarily an "egregious" ${ }^{\text {"67 }}$ First Amendment violation, it is perfectly acceptable when the government is doling out subsidies.

Rust v. Sullivan ${ }^{68}$ provides an example of a government subsidy straight from the Court's jurisprudence. In Rust, the federal government had a policy of supporting "preventive family planning services, population research, infertility services, and other related medical, informational, and educational activities." ${ }^{69}$ To further this policy, Congress passed Title X of the Public Health Services Act to give money to doctors to advise patients about family planning. Congress did not consider abortion to be within its family planning objectives, so it forbade doctors receiving money from discussing abortion with their patients. ${ }^{70}$ Some doctors receiving Title X money challenged this restriction as violating their free speech rights. Specifically, they "contend[ed] that the regulations violate[d] the First Amendment by impermissibly discriminating based on viewpoint because they prohibit all discussion about abortion as a lawful option... while compelling the clinic or counselor to provide information that promotes continuing a pregnancy to term.",71

The Supreme Court ruled that the Title X grants were government subsidies. Congress gave money to doctors for the purpose of promoting the government's own policies about family planning. As such, Congress could impose restrictions to ensure that the doctors were in fact furthering the government's policy objectives, even if that meant engaging in viewpoint discrimination. The Court said:

The Government can, without violating the Constitution, selectively fund a program to encourage certain activities it believes to be in the public interest, without at the same time funding an alternative program which seeks to deal with the problem in another way. In so doing, the Government has ... merely chosen to fund one activity to the exclusion of the other. A legislature's decision not to subsidize the

\footnotetext{
66 Velazquez, 531 U.S. at 541 (citations and quotations omitted).

67 Rosenberger, 515 U.S. at 829.

68500 U.S. 173 (1991).

69 Id. at $178-81$.

70 See id. at 178.

71 Id. at 192 (quotations omitted).
} 
exercise of a fundamental right does not infringe the right .... There is a basic difference between direct state interference with a protected activity and state encouragement of an alternative activity consonant with legislative policy. ${ }^{72}$

The prohibition on abortion counseling was necessary "to ensure that the limits of the federal program [were] observed." ${ }^{, 73}$

So if tax exemptions for religious organizations are subsidies - true subsidies in the technical, legal sense - then the IRS has the leeway to impose restrictions to ensure that the organizations advance the government's reasons for handing out the exemptions in the first place. According to this line of argument, the reason the government provides tax exemptions to charities, including religious organizations, is a recognition of the public benefit these organizations provide. ${ }^{74}$ Religious organizations that espouse the belief that marriage is only between one man and one woman cannot be viewed as conferring a public benefit and, therefore, the IRS can deny them a tax exemption. To exempt such bigoted organizations would run contrary to the government's policies undergirding tax exemptions. Therefore, the government can choose not to exempt them without raising any concerns under the Constitution. It is like UVA funding a speech by Dr. Cornelison but not the frat boy. Or Congress funding doctors promoting childbirth but not doctors promoting abortion. They are matters of government discretion and policymaking, and not matters of any constitutional magnitude.

But if the Establishment Clause of the First Amendment- the principle of separation of church and state-mandates tax exemptions for religious organizations, then the IRS has no discretion in the matter. The exemptions are not about a determination of whether particular religious organizations provide what the government believes is a "public benefit." Or even a government decision as to whether specific religious organizations further the IRS's policies behind the giving of tax exemptions. Rather, the government is obeying a constitutional command, in which case, a tax exemption for religious organizations cannot be denominated a subsidy. The government is adhering to the very structure of government dictated by the Constitution, not choosing which organizations best furthers its own agenda.

72 Id. at 193.

73 Id.

74 See, e.g., Bob Jones Univ. v. United States, 461 U.S. 574, 591 (1983) ("Charitable exemptions are justified on the basis that the exempt entity confers a public benefit - a benefit which the society or the community may not itself choose or be able to provide, or which supplements and advances the work of public institutions already supported by tax revenues."). 


\section{B. The Establishment Clause Forbids the Government from Intruding on the Autonomy of Religious Organizations}

The common understanding of the Establishment Clause of the First Amendment - or the separation of church and state - is that it prevents the government from doing religious "stuff." The person on the street accepts that the Establishment Clause means the government cannot set up a Methodist church, force public school students to worship Vishnu, or send tax dollars to the local mosque. But what is missing is an understanding of the flipside of separation of church and state. The Establishment Clause also means the government cannot monkey around with the autonomy of religious institutions. The Supreme Court put it this way: "[The Establishment Clause] radiates... a spirit of freedom for religious organizations, an independence from secular control or manipulation, in short, power to decide for themselves, free from state interference, matters of church government as well as those of faith and doctrine., 75

Presbyterian Church v. Mary Elizabeth Blue Hull Memorial Presbyterian Church ${ }^{76}$ for example, presented the Supreme Court with a dispute between a Presbyterian denomination, and two of its local congregations over the control of properties in Georgia. The controversy began when the local churches sought to leave the denomination and take their property with them. The churches believed that the denomination's apparent abandonment of traditional, orthodox Christian beliefs justified leaving with their property. ${ }^{77}$ The lower court held in favor of the local churches, finding

75 Kedroff v. St. Nicholas Cathedral of Russian Orthodox Church in N. Am., 344 U.S. 94, 116 (1952); see also Watson v. Jones, 80 U.S. 679 (1871). The Watson Court clearly premised its holding in terms of lack of jurisdiction or power:

But it is a very different thing where a subject-matter of dispute, strictly and purely ecclesiastical in its character, - a matter over which the civil courts exercise no jurisdiction, - a matter which concerns theological controversy, church discipline, ecclesiastical government, or the conformity of the members of the church to the standard of morals required of them,--becomes the subject of its action. It may be said here, also, that no jurisdiction has been conferred on the tribunal to try the particular case before it, or that, in its judgment, it exceeds the powers conferred upon it, or that the laws of the church do not authorize the particular form of proceeding adopted; and, in a sense often used in the courts, all of those may be said to be questions of jurisdiction. But it is easy to see that if the civil courts are to inquire into all these matters, the whole subject of the doctrinal theology, the usages and customs, the written laws, and fundamental organization of every religious denomination may, and must, be examined into with minuteness and care, for they would become, in almost every case, the criteria by which the validity of the ecclesiastical decree would be determined in the civil court. This principle would deprive these bodies of the right of construing their own church laws... and would, in effect, transfer to the civil courts where property rights were concerned the decision of all ecclesiastical questions.

Id. at 733-34.

76393 U.S. 440 (1969).

77 See id. at 441-43. 
that the denomination had in fact left behind orthodox beliefs and thereby given up any right to the contested property. ${ }^{78}$

On appeal, the Supreme Court held that the Establishment Clause precluded the courts from becoming involved in the dispute, since it necessarily turned on a determination of what constituted orthodox Christian beliefs. The "American concept of the relationship between church and state... leaves the civil courts no role in determining ecclesiastical questions in the process of resolving property disputes." "If "If civil courts undertake to resolve [doctrinal] controversies in order to adjudicate the property dispute, the hazards are ever present of inhibiting the free development of religious doctrine and of implicating secular interests in matters of purely ecclesiastical concern." church and state mandated by the Establish-ment Clause prevented the courts from exercising jurisdiction over the religious dispute.

The Court has regularly extended this same protection to the autonomy of private religious schools. For example, in NLRB v. Catholic Bishop of Chicago, ${ }^{81}$ teachers at two Catholic high schools filed petitions with the National Labor Relations Board accusing the schools of unfair labor practices. The schools moved to dismiss the petitions claiming that the Establishment Clause precluded the Board from asserting jurisdiction. The Court agreed, holding that "the Establishment Clause of the First Amendment foreclosed the Board's jurisdiction." 82 The Court reasoned:

The resolution of [the unfair labor] charges by the Board, in many instances, will necessarily involve inquiry into the good faith of the position asserted by the clergy-administrators and its relationship to the school's religious mission. It is not only the conclusions that may be reached by the Board which may impinge on rights guaranteed by the Religion Clauses, but also the very process of inquiry leading to findings and conclusions.... Inevitably the Board's inquiry will implicate sensitive issues that open the door to conflicts between clergy-administrators and the Board, or conflicts with negotiators for unions. $^{83}$

The Establishment Clause required the Court to interpret the Act to avoid "a significant risk that the First Amendment will be infringed." 84 The Court

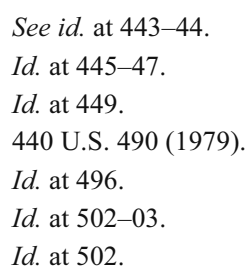


said, "[W]e decline to construe the Act in a manner that could in turn call upon the Court to resolve difficult and sensitive questions arising out of the guarantees of the First Amendment Religion Clauses." $" 85$

Most recently, the Court unanimously held that the Establishment Clause barred it from considering a claim brought under the Americans with Disabilities Act (ADA) by a former employee against a private Lutheran elementary school. ${ }^{86}$ Cheryl Perich worked at the school teaching a variety of subjects, including math, language arts, social studies, science, gym, art, music, and religion. She became ill with narcolepsy and could no longer teach. The school placed Perich on disability and then eventually asked her to resign when it appeared she "was unlikely to be physically capable of returning to work." ${ }^{\circ 77}$ Perich became upset and refused to resign. Instead of resolving the dispute peaceably, Perich threatened to sue under the ADA. The school subsequently fired her because "her threat to sue the [school] violated the Synod's belief that Christians should resolve their disputes internally." ${ }^{\prime 8}$ Perich subsequently made good on her threat and sued the school under the ADA.

The Court refused to hear Perich's claim. "[T]he First Amendment requires dismissal of this employment discrimination suit against her religious employer." ${ }^{\prime 89}$ Applying the ADA to the school, said the Court, "intrudes upon more than a mere employment decision." "The First Amendment "protects a religious group's right to shape its own faith and mission through its appointments." 91 For the Court to second guess the school's decisions in this case would trench on that right. Separation of church and state, said the Court, "bars such a suit." 92

Thus, the Establishment Clause not only forecloses the government from affirmatively supporting religion, but, more pertinently, shuts the government out of religious matters. The government cannot tread into the realm reserved for religion. It is precisely this concern that is raised by the threat of stripping religious schools of their tax-exempt status. ${ }^{93}$

$85 \quad$ Id. at 507.

86 See Hosanna-Tabor Evangelical Lutheran Church and Sch. v. EEOC, 132 S. Ct. 694, 701 (2012).

87 Id. at 700.

88 Id. at 701.

89 Id. at 709

$90 \quad I d$. at 706.

$91 \quad I d$.

$92 \quad$ Id. at 710

93 Hypothetically, the Religious Freedom Restoration Act, 42 U.S.C. $\S 2000$ bb to 42 U.S.C. § 2000bb-4 (2015), bolsters a religious organization's claim for an exemption from the federal income tax. However, Bob Jones is a part of the body of religious liberty law that predates Employment Division $v$. 


\section{The Supreme Court's Treatment of Religious Tax Exemptions}

A review of the relevant Supreme Court cases shows that the Court's treatment of religious tax exemptions has been, at best, erratic. But one constant runs through all the cases. The Court has always tied the constitutionality of religious tax exemptions to concerns about separation of church and state. That constancy suggests that such exemptions are an acknowledgement of the autonomy of religious organizations rather than a subsidy of religion.

\section{A Survey of the Relevant Supreme Court Cases}

A review of the pertinent cases starts with Murdock v. Pennsylvania ${ }^{94}$ and Follett v. Town of McCormick. ${ }^{95}$ The most interesting feature of Murdock and Follett is that the tax exemptions in those cases were created by the Court itself, based on an understanding of the imperatives of the First Amendment. The Court recognized the exemptions as being constitutionally compelled rather than being within the discretion of the legislature.

Both Murdock and Follett involved municipal ordinances imposing a licensing tax on persons selling goods and merchandise in the community. In both cases, the cities taxed the Jehovah's Witnesses for going "door to door... distributing literature and soliciting people to purchase certain religious books and pamphlets, all published by the Watch Tower Bible \& Tract Society." 96

The Murdock Court held that the First Amendment required an exemption for the Jehovah's Witnesses' canvassing activities. Echoing the language of McCulloch v. Maryland, ${ }^{97}$ the Court said that allowing the City of Jeannette to tax religious exercise would have a "destructive effect." 98 "The power to impose a license tax on the exercise of these freedoms," said the Court, "is indeed as potent as the power of censorship which this Court has repeatedly struck down." ${ }^{99}$ The Court went on:

The power to tax the exercise of a privilege is the power to control or suppress its enjoyment. Those who can tax the exercise of this religious practice can make its exercise so costly as to deprive it of the

Smith, 494 U.S. 872 (1990), that Congress intended for RFRA to "restore." As such, it is not clear that RFRA adds anything to the discussion.

94319 U.S. 105 (1943).

95321 U.S. 573 (1944).

96 Murdock, 319 U.S. at 106-07.

9717 U.S. 316 (1819).

98 Murdock, 319 U.S. at 113.

$99 \quad I d$. 
resources necessary for its maintenance. Those who can tax the privilege of engaging in this form of missionary evangelism can close its doors to all those who do not have a full purse. ${ }^{100}$

Even though the city's licensing tax contained no exemption for religious organizations, the First Amendment mandated that one being given.

A year later, Follett confirmed the constitutional necessity of tax exemptions for religious organizations. The Court again concluded that the First Amendment required exemption from a municipality's flat licensing tax for the Jehovah's Witnesses' religious solicitors.

The exaction of a tax as a condition to the exercise of the great liberties guaranteed by the First Amendments is as obnoxious as the imposition of a censorship or a previous restraint. For, to repeat, "the power to tax the exercise of a privilege is the power to control or suppress its enjoyment."101

Justice Murphy drove home the need for religious tax exemptions in his concurrence. "It is wise to remember," he said, "that the taxing and licensing power is a dangerous and potent weapon which, in the hands of unscrupulous or bigoted men, could be used to suppress freedoms and destroy religion unless it is kept within appropriate bounds." 102

The Follett Court rejected the characterization of a tax exemption for the Jehovah's Witnesses as a subsidy. "This does not mean that religious undertakings must be subsidized," said the Court. ${ }^{103}$ Rather, our holding is a recognition that religious organizations cannot "be required to pay a tax for the exercise of that which the First Amendment has made a high constitutional privilege." 104

The lion's share of the Supreme Court's consideration of religious tax exemptions after Murdock and Follett addressed whether such exemptions were permissible under the Establishment Clause, not whether the exemptions were in fact required by the Constitution. The cases arose when taxpayers sued, arguing that a state's provision of tax exemptions to religious institutions ran afoul of the Establishment Clause by impermissibly endorsing religion. Nonetheless, the cases bear directly on our question of whether such religious tax exemptions are a subsidy or a constitutionally compelled recognition of the autonomy of religious

$100 \quad I d$. at 112 (citations omitted).

101 Follett v. Town of McCormick, 321 U.S. 573, 577 (1944) (quoting Murdock, 319 U.S. at 112) (citations omitted).

102 Id. at 579 (Murphy, J., concurring).

103 Id. at 577.

104 Id. at 578. 
institutions.

The Court again grounded the constitutionality of religious tax exemptions in separation concerns in Walz v. Tax Commission of the City of New York. ${ }^{105}$ In Walz, an owner of real property in Richmond County, New York sued the New York City Tax Commission arguing that "granting property tax exemptions to religious organizations for religious properties used solely for religious worship" violated the Establishment Clause of the First Amendment. ${ }^{106}$ The Supreme Court disagreed and upheld the exemption.

Writing for the Walz majority, Chief Justice Burger explained that the goal of religious tax exemptions is "to avoid excessive entanglement" 107 of government and religious institutions, thereby "prevent[ing] the kind of involvement that would tip the balance toward government control of churches or governmental restraint on religious practice."108 The New York property tax exemption, said Burger, springs from a constitutionally-based concern with "the autonomy and freedom of religious bodies." 109 Such bodies "should not be inhibited in their activities by property taxation or the hazard of loss of those properties for nonpayment of taxes." 110

Grants of exemption historically reflect the concern of authors of constitutions and statutes as to the latent dangers inherent in the imposition of property taxes; exemption constitutes a reasonable and balanced attempt to guard against those dangers .... Elimination of exemption would tend to expand the involvement of government by giving rise to tax valuation of church property, tax liens, tax foreclosures, and the direct confrontations and conflicts that follow in the train of those legal processes.... The exemption creates only a minimal and remote involvement between church and state and far less than taxation of churches. It restricts the fiscal relationship between church and state, and tends to complement and reinforce the desired separation insulating each from the other. ${ }^{111}$

Despite the Walz Court's forceful language about church, state separation, it did not hold that religious tax exemptions were constitutionally required, as it had in Murdock and Follett. Rather, the Court held that the New York tax exemption was a constitutionally "permissible state accommodation" of

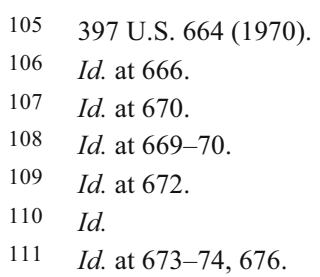


religious institutions. ${ }^{112}$ The First Amendment permits states to exempt religious institutions, but it does not require it.

Noteworthy for our purposes, the Court refused to categorize religious tax exemptions as government subsidies. A "subsidy would be a relationship pregnant with involvement and, as with most governmental grant programs, could encompass sustained and detailed administrative relationships for enforcement of statutory or administrative standards, but that is not this case." 113 New York did not exempt religious organizations from property taxes to further its own program of social welfare, i.e., religious organizations provide a "public benefit" that the state "considers... as beneficial and stabilizing influence[s] in community life." 114 Instead, New York "is simply sparing the exercise of religion from the burden of property taxation levied on private profit institutions." 115 Paulsen explains:

Walz expressly disclaimed a "public benefit" theory for justifying tax exemption of religious organizations. The rationale upon which the Court upheld the New York statute in Walz was that tax-exemption seeks to protect free exercise, foster diversity, and minimize governmental interference. ${ }^{116}$

Justice Brennan, in his concurrence, is more direct. He pushes aside "those who ... argue that exemptions are the equivalent of governmental subsidy of churches.... Tax exemptions and general subsidies, however, are qualitatively different."117

Walz, thus, dismisses the idea that religious tax exemptions are a government subsidy. Though the case does not require religious tax exemptions, it solidly roots the constitutionality of such exemptions in concerns about the autonomy of religious institutions.

The Court reached a seemingly opposite result in Texas Monthly $v$. Bullock. ${ }^{118}$ The case involved a Texas sales tax statute that applied to all publications except "[p]eriodicals that are published or distributed by a religious faith and that consist wholly of writings promulgating the teaching of the faith and books that consist wholly of writings sacred to a religious

$112 I d$. at 673.

$113 I d$. at 675 (emphasis added).

114 Id. at 673.

115 Id.

116 Michael Stokes Paulsen, Religion, Equality, and the Constitution: An Equal Protection Approach to Establishment Clause Adjudication, 61 NOTRE DAME L. REV. 311, 363-64 (1986).

117 Walz, 397 U.S. at 690 (Brennan, J., concurring).

118489 U.S. 1 (1989). 
faith."119 The narrow statutory exemption aimed squarely at religious publications. Texas Monthly, a secular magazine publisher, challenged the religious tax exemption as violative of the Establishment Clause. A plurality of the Court agreed. But even in striking the exemption down, the plurality expressed worry over "enmesh[ing] the operations of church and state." ${ }^{20}$ Not just that the Texas may be impermissibly favoring religion, but that the state may be meddling with religious institutions in a way that treads on their autonomy.

The plurality said that Texas' sales tax exemption "lacks sufficient breadth to pass scrutiny under the Establishment Clause." ${ }^{121}$ Such a narrow exemption inevitably entangles the state in religion. The exemption, the plurality said:

appears, on its face, to produce greater state entanglement with religion than the denial of an exemption. As Justice Stevens has noted: "There exists an overriding interest in keeping the government - whether it be the legislature or the courts - out of the business of evaluating the relative merits of differing religious claims. The risk that governmental approval of some and disapproval of others will be perceived as favoring one religion over another is an important risk the Establishment Clause was designed to preclude." The prospect of inconsistent treatment and government embroilment in controversies over religious doctrine seems especially baleful where, as in the case of Texas' sales tax exemption, a statute requires that public officials determine whether some message or activity is consistent with "the teaching of the faith." 122

The plurality discussed and cited approvingly Justice Harlan's concurrence from Walz. ${ }^{123}$ The tax exemption in Walz applied to "real or personal property used exclusively for religious, educational or charitable purposes," not just religious purposes. ${ }^{124}$ Justice Harlan linked the breadth of the exemption in Walz with entanglement concerns, concluding that there is less entanglement danger when a tax exemption is broad.

$119 I d$. at 5 (citations and quotations omitted).

120 Id. at 21.

121 Id. at 14

122 Id. at 20 (quoting United States v. Lee, 455 U.S. 252, 263 n.2 (1982) (Stevens, J., concurring)) (citations omitted). In raising these concerns, the Court cited to the line of cases where it recognized the Establishment Clause's protection of religious autonomy-cases like Jones v. Wolf, 443 U.S. 595 (1979), Serbian Eastern Orthodox Diocese v. Milivojevich, 426 U.S. 696 (1976), and Presbyterian Church in the United States v. Mary Elizabeth Blue Hull Memorial Presbyterian Church, 393 U.S. 440 (1969).

123 See Texas Monthly, 489 U.S. at 13.

124 Walz v. Tax Comm'n of N.Y.C., 397 U.S. 664, 666-67 (1970). 
In the instant case noninvolvement is further assured by the neutrality and breadth of the exemption. In the context of an exemption so sweeping as the one before us here its administration need not entangle government in difficult classifications of what is or is not religious, for any organization - although not religious in a customary sense-would qualify under the pervasive rubric of a group dedicated to the moral and cultural improvement of men. Obviously the more discriminating and complicated the basis of classification for an exemption-even a neutral one-the greater the potential for state involvement in evaluating the character of the organizations. ${ }^{125}$

In other words, the religious tax exemption in Walz furthered church, state separation by avoiding entangling the State of New York in the affairs of religious institutions. Whereas the religious tax exemption in Texas Monthly did just the opposite. It was so narrowly drawn that it necessarily required the State of Texas to troll through religious publications to determine whether or not they in fact "promulgat[ed] the teaching of the faith." ${ }^{, 26}$ It increased church, state entanglement rather than minimized it.

The plurality, throughout its opinion, labeled Texas' tax exemption as a "subsidy." But it is, as Professor Zelinsky has observed, "invoked in a reflexive fashion." 127 Of course, in a colloquial sense, religious tax exemptions provide "pecuniary aid" to religious organizations. That does not mean the plurality believed that Texas' exemption was a "subsidy" in the technical, legal sense. Texas did not provide the exemption because it viewed the religious periodicals as promoting the state's own program or message. Rather, as the lower court found, Texas passed the exemption with the "purpose of preserving separation between church and state." 128 The plurality disagreed that the exemption accomplished this purpose but it did not dispute that it was the state's objective.

Moreover, if the plurality truly believed Texas' exemption was a subsidy, then that should have been the end of the case. It flatly violates the Establishment Clause for the government to subsidize a religious organization for the purpose of sending a religious message. The very fact that the Court did not treat the case as open-and-shut means it did not believe Texas was paying religious publications to send the state's own message. Yes, the Court concluded that the exemption was a "blatant endorsement of religion." ${ }^{, 29}$ But it went on to consider the "degree of state 
entanglement in religious affairs." ${ }^{\prime 130}$ That would not have been necessary if the exemption was a true subsidy.

So the Texas Monthly court continued to root the constitutionality of tax exemptions in separation of church and state concerns. Specifically, whether the exemption impermissibly entangled the government with religious matters. The Court concluded that Texas' narrow tax exemption for religious publications resulted in forbidden entanglement. It required the state to wade into whether magazines and books were sufficiently religious to fall within the state's tax exemption. The Court labeled the exemption as a subsidy, but did so only reflexively. It did not in fact treat Texas' exemption as a true subsidy.

The Court's earlier decision in Mueller v. Allen ${ }^{131}$ contrasts with Texas Monthly, showing that a broader tax help, that avoids meddling with the autonomy of religious institutions, passes constitutional muster. In Mueller, the Court sustained against First Amendment challenge a Minnesota income tax deduction for parents' expenses for their children's elementary and secondary educations. Unlike the narrow tax exemption the Court struck down in Texas Monthly, Minnesota's tax deduction covered "educational expenses incurred by all parents, including those whose children attend[ed] public schools and those whose children attend[ed] non-sectarian private schools or sectarian private schools." "132 So it "permit[ted] all parentswhether their children attend[ed] public school or private- to deduct their children's educational expenses." 133 For example, the deduction was available if a parent living in one public school district paid tuition to send her child to a public school in another district. Or if a public school parent pays for "[c]ertain summer school tuition." ${ }^{\text {"134 }}$ Expenses incurred by parents sending their children to private religious school were also included, but those expenses were only one small part of the program.

The breadth of Minnesota's deduction differentiates it from Texas' exemption. The Court said, "[A] program, like [Minnesota's], that neutrally provides state assistance to a broad spectrum of citizens is not readily subject to challenge under the Establishment Clause." 135 The Court again tied the constitutionality to entanglement concerns. The broad nature of the deduction led the Court to adjudge, "[W]e have no difficulty in concluding that the Minnesota statute does not 'excessively entangle' the state in

\footnotetext{
$130 \quad$ Id. at 20 n.9.

131463 U.S. 388 (1983).

$132 I d$. at 397 (emphasis in original).

$133 I d$. at 398 (emphasis in original).

134 Id. at 391 n.2.

135 Id. at 398-99.
} 
religion." "136 Any decisions the state has to make about whether particular expenses qualify for the deduction, the Court said, "do... not differ substantially from making the types of decisions approved in earlier opinions of this Court." ${ }^{137}$ Minnesota had no need to sift through parental expenses to see if the private schools where they were spending money were religious enough to qualify for the deduction. The deduction applied across the board to all educational expenses - whether incurred at religious or nonreligious institutions.

The income tax exemption provided by the IRS to religious organizations under Section 501(c)(3) falls firmly on the Mueller v. Allen side of the line. ${ }^{138}$ Like Minnesota's tax deduction, the 501(c)(3) exemption is broadly defined. It applies to any "[c]orporations, and any community chest, fund, or foundation, organized and operated exclusively for religious, charitable, scientific, testing for public safety, literary, or educational purposes, or to foster national or international amateur sports competition . . , or for the prevention of cruelty to children or animals." 139 Section 501(c)(3), unlike the tax exemption in Texas Monthly, does not direct a benefit "exclusively to religious organizations." 140 Rather, the exemption applies to the complete spectrum of nonprofit corporations.

The breadth of the 501(c)(3) exemption means the IRS does not need to scrutinize how religious an organization is for it to qualify for tax-exempt status. Most religious organizations serve more than one purpose. For instance, a private religious school, like Wheaton College in Illinois, ${ }^{141}$ operates both for a religious purpose and for an educational purpose. Likewise, a Christian humanitarian aid organization, like World Vision International, ${ }^{142}$ operates both for a religious purpose and for a charitable purpose. In each instance, either purpose is sufficient to qualify the religious organization for 501(c)(3) status. Just how religious these organizations really are is not determinative of whether they meet the criteria for tax-exempt status.

And even when the IRS does consider whether an organization has a religious purpose, its inquiry is limited. The Internal Revenue Manual, the internal protocols for IRS personnel, gives examination guidelines for religious activities. The guidelines say, "Under the First Amendment, the

\footnotetext{
136 Id. at 403.

137 Id.

138 See Mueller v. Allen, 463 U.S. 388 (1983).

13926 U.S.C. $\$ 501(c)(3)(2015)$.

140 Texas Monthly, Inc. v. Bullock, 489 U.S. 1, 15 (1989).

141 See Wheaton COLlege, www.wheaton.edu (last visited Sept. 10, 2015).

142 See WORLD ViSION INT'L, www.worldvision.org (last visited Sept. 10, 2015).
} 
IRS can't consider the content or sources of a doctrine alleged to constitute a particular religion. The IRS also can't evaluate the content of a doctrine an organization claims is religious." $" 143$ In other words, the IRS must give deference to what the organization calls religious. It cannot stick its nose into the religious organization's operations and beliefs to sniff out if they are religious enough to qualify for an exemption.

Moreover, the most likely organizations to apply for 501(c)(3) status solely on the ground of having a religious purpose-meaning they do not also fall under some other category like educational or charitable-are churches. And churches are special. Most organizations seeking tax-exempt status are required to apply to the IRS for an advance determination that they meet the requirements of Section 501(c)(3). But churches do not. ${ }^{144} \mathrm{~A}$ church may simply hold itself out as tax exempt and receive the benefits of that status without applying for advance recognition from the IRS. ${ }^{145}$ So there is no determination made by the IRS at all. That means there cannot possibly be any entanglement with religion when it comes to churches and tax-exempt status.

Even beyond religious organizations, applications for 501(c)(3) status just generally receive little scrutiny from the IRS. During fiscal year 2014, for example, the IRS disapproved only 67 applications out of the 100,032 total 501(c)(3) applications submitted. ${ }^{146}$ A report from the Stanford University Center on Philanthropy and Civil Society concluded, "Nearly every application on which a decision is rendered is approved." "It7 "It is hardly an exaggeration," said the report, "to say that when it comes to oversight of the application process to become a public charity, nearly anything goes." 148 Whatever allegations can be made about the process of religious organizations applying for 501(c)(3), it is certainly not that the process impermissibly entangles the IRS with religion. The process, if anything, furthers the separation concerns that drive the recognition of a religious tax exemption in the first place.

143 Internal Revenue Serv., Internal Revenue Manual, Part 4.76.6 (Oct. 24, 2014), www.irs.gov/irm/part4/irm_04-076-006.html.

144 See 26 U.S.C. $\$ 508$ (c) (2015).

145 See Internal Revenue Serv., TAX Guide for Churches \& Religious Organizations 2 (2015), www.irs.gov/pub/irs-pdf/p1828.pdf.

146 See InTERnal Revenue SeRv., DATA BooK 57 (2014), www.irs.gov/pub/irs-soi/14databk. pdf.

147 Rob Reich, Lacy Dorn \& Stefanie Sutton, ANything Goes: Approval of NonProfit Status by the IRS, Stanford Univ. Ctr. ON Philanthropy ANd Civ. SoC'y 4 (2009), http://pacscenter.stanford.edu/wp-content/uploads/2015/08/Anything-Goes-PACS-11-09.pdf.

$148 \quad I d$. 
At first blush, the Supreme Court's follow up to Texas Monthly- the decision in Jimmy Swaggart Ministries v. Board of Equalization ${ }^{149}$ appears to undermine the argument that the IRS is constitutionally compelled to exempt religious organizations from income taxation. In the case, Jimmy Swaggart Ministries sold religious merchandise in California and claimed a constitutional right to a sales tax exemption. A unanimous Supreme Court rejected this claim. "The Free Exercise Clause," said the Court, "does not require the State to grant appellant an exemption from its generally applicable sales and use tax." 150 Jimmy Swaggart Ministries could avoid any alleged burden on its free exercise rights simply by not selling cups, books, tapes, and other swag in the State of California.

Swaggart is thus a limited opinion. It involved the imposition of unrelated business income tax on the sale of merchandise by a religious organization. The Court explained, "[I]t is a tax on the privilege of making retail sales of tangible personal property and on the storage, use, or other consumption of tangible personal property in California."151 Jimmy Swaggart Ministries fell under California's sales and use tax because it sold merchandise in the state, not just because it operated in the state. It was not the religious services, the preaching, or the hymn singing that California taxed. It was the side business of selling merchandise. Like anyone else selling things in the state, Jimmy Swaggart Ministries had to pay a tax on these sales.

This fact makes California's sales and use tax distinct from something like the federal income tax under consideration in this article. A religious organization falls under an income tax merely by existing and carrying on its operations. Like any other organization or business, religious organizations need revenue to survive. For religious organizations, revenue typically comes from donations, tithes, and grants. To the extent this revenue exceeds the organization's expenses - the money spent on items like wages, office supplies, janitorial services, and toilet paper-the organization has income. God willing, every religious organization has income or else it will not last long. In a for-profit business, that difference between revenue and expenses represents taxable income. The for-profit business must pay federal corporate income tax at rate of fifteen to thirtynine percent depending on exactly how much taxable income it has. And, but for the existence of religious tax exemptions at the federal and state levels, religious organizations would have taxable income too. So a religious organization can avoid a sales and use tax, but, absent some type

149493 U.S. 378 (1990).

$150 \quad$ Id. at 392 (emphasis in original).

151 Id. at 389-90 (emphasis added). 
of exemption, not an income tax.

Just as significantly, a sales tax and an income tax differ as to the centrality of the activity they tax. A sales and use tax is aimed at a secondary part of a religious organization's enterprise - selling swag, food, or other items. Those sales are subsidiary to the organization's primary activity of ministering. As the Swaggart Court said, "[T]he collection and payment of the generally applicable [sales] tax in this case imposes no constitutionally significant burden on appellant's religious practices or beliefs." $" 152$ In contrast, an income tax is aimed at the heart of what religious organizations do. It taxes religious organizations simply for existing and engaging in religious activities. The Swaggart Court recognized this kind of tax "might effectively choke off an adherent's religious practices." 153

California itself recognizes these distinctions. It imposes a sales and use tax on religious organizations because the state understands this does not raise "[t]he sorts of government entanglement that [the Supreme Court Justices] have found to violate the Establishment Clause." ${ }^{154}$ Such a tax is not, as the Court said, "invasive." ${ }^{155}$ Religious organizations can just choose not to sell things in the state. But California still maintains income tax exemptions for religious and educational organizations because an income tax is "invasive." the tax simply by existing and ministering within the state's borders. An income tax cannot be avoided. It opens the possibility of the state taxing a religious organization out of existence.

The Court in Swaggart, just as it did in the prior religious tax exemption cases, considered whether the California sales tax resulted in "administrative entanglement." 157 The Court concluded that it did not.

Most significantly, the imposition of the sales and use tax without an exemption for appellant does not require the State to inquire into the religious content of the items sold or the religious motivation for selling or purchasing the items, because the materials are subject to the tax regardless of content or motive. From the State's point of view, the critical question is not whether the materials are religious, but whether there is a sale or a use, a question which involves only a secular

\footnotetext{
152 Id. at 392.

153 Id.

154 Id. at $395-96$.

155 Id. at 396.

156 See CAL. REV. \& TAX. CODE $§ 23701 \mathrm{~d}$ (West 2015).

157 Jimmy Swaggart Ministries, 493 U.S. at 394.
} 
determination. ${ }^{158}$

The sales and use tax applied to all commerce in the state, whether religious or nonreligious. The kind of narrow, religion-specific exemption that Jimmy Swaggart Ministries requested would have ensnared the state in religion just like the religious tax exemption in Texas Monthly.

\section{The Ramifications of the Supreme Court's Case Law}

So what should we make of the Court's seemingly erratic treatment of religious tax exemptions? At bottom, that whatever the apparent discrepancies, the Court has a steadfast concern for the protection of religious autonomy. At least four observations can be made.

First, the Court has consistently recognized that taxing religious organizations is fraught with constitutional hazards. Way back in Murdock, the Court cautioned about the "destructive effect" of allowing the government to tax religion. ${ }^{159}$ In Follett, the Court said, "[T] he taxing and licensing power is a dangerous and potent weapon which, in the hands of unscrupulous or bigoted men, could be used to suppress freedoms and destroy religion unless it is kept within appropriate bounds." ${ }^{~ 160}$ In Walz, the Court warned of the "latent dangers inherent in the imposition of property taxes" on religious organizations. ${ }^{161}$ It said that a religious tax exemption "constitute[d] a reasonable and balanced attempt to guard against those dangers." 162 In Texas Monthly, the Court noted that taxing religious organizations poses a "danger of stamping out missionary work" and risks becoming "a covert attempt to curtail religious activity." 163 In Mueller, the Court said that the relationship between taxes, tax benefits, and religious organizations raises "evils against which the Establishment Clause was designed to protect." "164 "[G]overnment involvement in religious life," said the Court, "is apt to lead to strife." 165 The persistent drumbeat of the Court has been that taxing religious organizations jeopardizes their constitutionally protected autonomy.

Second, the constitutionality of religious tax exemptions hinges on their impact on the autonomy of religious organizations. The First

\footnotetext{
158 Id. at 396.

159 Murdock v. Pennsylvania, 319 U.S. 105, 113 (1943).

160 Follett v. City of McCormick, 321 U.S. 573, 579 (1944) (Murphy, J., concurring).

161 Walz v. Tax Comm'n of N.Y.C., 397 U.S. 664, 673 (1970).

$162 I d$

163 Texas Monthly, Inc. v. Bullock, 489 U.S. 1, 24 (1989).

164 Mueller v. Allen, 463 U.S. 388, 399. (1983).

165 Id. at 399-400 (quoting Comm. for Pub. Educ. v. Nyquist, 413 U.S. 756, 796 (1973)) (quotations and citations omitted).
} 
Amendment compelled an exemption for the Jehovah's Witnesses from the flat taxes in Murdock and Follett because the taxes acted as a "restraint on the free exercise of religion." 166 The religious exemption from New York's property tax in Walz was constitutional because it served to accommodate "the autonomy and freedom of religious bodies." 167 The narrow religious exemption from the sales tax in Texas Monthly was unconstitutional because of "the degree of state entanglement in religious affairs." ${ }^{168}$ It required state officials "to subject the content of religious publications to . . . exacting scrutiny" in a way that "enmesh[ed] the operations of church and state." 169 The tax deduction in Mueller was upheld because it did "not 'excessively entangle' the State in religion." required state to intrude on the affairs of private religious schools. Taxing the ancillary merchandise sales of religious organizations raised no Establishment Clause problems in Jimmy Swaggart because the Court found "no excessive entanglement between government and religion." 171 The state stayed out of the business religious organizations - it was "not require[d] ... to inquire into the religious content of the items sold or the religious motivation for selling or purchasing the items." cases, the root of what made the tax exemptions constitutional or unconstitutional was the repercussions on the self-rule of religious organizations.

Third, whether a tax impermissibly encroaches on the autonomy of religious organizations depends on what activity the government chooses to tax. When the government taxes a collateral part of what religious organizations do, like the sale of t-shirts, stickers, and mugs as in Jimmy Swaggart, it does not raise the same concerns about religious autonomy as when the government taxes religious organizations' central operations and ministry, like the tax on the Jehovah's Witnesses' "missionary evangelism" in Murdock.

In Murdock, the city's flat tax transgressed the separation of church and state because the tax fell squarely on the Jehovah's Witnesses' religious activity - their door-to-door evangelism. The Court specifically rejected the characterization of such evangelism as "merely incidental and collateral to

\footnotetext{
166 Murdock v. Pennsylvania, 319 U.S. 105, 117 (1943).

167 Walz, 397 U.S. at 672.

168 Texas Monthly, 489 U.S. at 20 n.9.

$169 I d$. at 20 nn. 9 \& 21.

170 Mueller, 463 U.S. at 403.

171 Jimmy Swaggart Ministries v. Bd. of Equalization of Cal., 493 U.S. 378, 397 (1990).

172 Id. at 396.
} 
their main object" as a religious organization. ${ }^{173}$ Rather, the Court deemed the Jehovah's Witnesses' canvassing to be core religious exercise.

The hand distribution of religious tracts is an age-old form of missionary evangelism - as old as the history of printing presses. It has been a potent force in various religious movements down through the years. This form of evangelism is utilized today on a large scale by various religious sects whose colporteurs carry the Gospel to thousands upon thousands of homes and seek through personal visitations to win adherents to their faith. It is more than preaching; it is more than distribution of religious literature. It is a combination of both. Its purpose is as evangelical as the revival meeting. This form of religious activity occupies the same high estate under the First Amendment as do worship in the churches and preaching from the pulpits. It has the same claim to protection as the more orthodox and conventional exercises of religion. ${ }^{174}$

Allowing the city to tax the Jehovah's Witnesses' door-to-door evangelism threatened to shut their religious exercise down altogether.

Those who can tax the exercise of this religious practice can make its exercise so costly as to deprive it of the resources necessary for its maintenance. Those who can tax the privilege of engaging in this form of missionary evangelism can close its doors to all those who do not have a full purse. Spreading religious beliefs in this ancient and honorable manner would thus be denied the needy. Those who can deprive religious groups of their colporteurs can take from them a part of the vital power of the press which has survived from the Reformation. ${ }^{175}$

That stands in contrast to the sales tax in Jimmy Swaggart. California's tax in that case fell "on the privilege of making retail sales of tangible personal property." 176 Unlike the city's tax on the Jehovah's Witness doorto-door evangelism in Murdock, California taxed the ministry's sale of merchandise, not its religious activities. "[T] he sales and use tax," the Court said, "is not a tax on the right to disseminate religious information, ideas, or beliefs." "177

California taxed only an ancillary part of Jimmy Swaggart's activities - the selling of items like "t-shirts with JSM logo, mugs, bowls,

173 Murdock v. Pennsylvania, 319 U.S. 105, 111-12 (1943).

$174 I d$. at $108-09$

175 Id. at 112.

176 Jimmy Swaggart Ministries, 493 U.S. at 389-90.

177 Id. at 389. 
plates, replicas of crown of thorns, ark of the covenant, Roman coin, candlesticks, Bible stand, pen and pencil sets, prints of religious scenes, bud vase, and communion cups." "There [was] no danger," said the Court, "that appellant's religious activity [was] being singled out for special and burdensome treatment." 179 The "tax merely decrease[d] the amount of money appellant ha[d] to spend." $" 180$

The Court specifically distinguished the flat tax imposed on the Jehovah's Witnesses in Murdock. "[T] he burden of a flat tax could render itinerant evangelism crushed and closed out by the sheer weight of the toll or tribute which is exacted town by town.", "But," said the Court, "we face no such situation in this case." 182 Any intrusion on religious autonomy affected by the sales and use tax was minimal at best. So a tax imposed on a collateral part of a religious organization's undertakings does not raise the same concerns regarding church, state separation as a tax aimed at its necessary day-to-day operations.

Fourth, and finally, the Court has often used the "subsidy" label in a conclusory fashion, giving no real consideration to whether the government is doling out tax exemptions to religious organizations for the purpose of advancing its own message and agenda. Recall that initially, the Court in Murdock, Follett, and Walz eschewed the "subsidy" label altogether. "Tax exemptions and general subsidies ... are qualitatively different .... Tax exemptions, accordingly, constitute mere passive state involvement with religion and not the affirmative involvement characteristic of outright governmental subsidy." "183 Things changed in Texas Monthly. The Court deemed Texas' sales tax exemption for religious publications a "subsidy." Yet the Court readily acknowledged that the state had the "purpose of preserving separation between church and state," and not a purpose of furthering its own favored message. ${ }^{184}$ The exemption, thus, could not be said to meet the technical definition of a subsidy.

The upshot is that the religious tax exemption in Section 501(c)(3) seems much more likely to be about protecting the autonomy of religious organizations than giving them a subsidy. The federal income tax has peak potential for a "destructive effect" on religious organizations. Religious organizations, like any business, depend on income as their lifeblood.

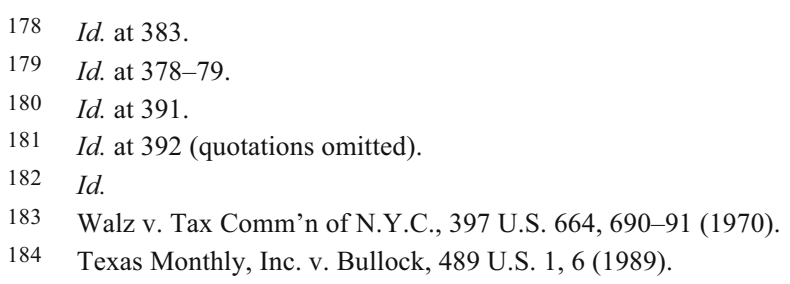


Earning income is part and parcel of their everyday operations. Religious organizations obviously cannot avoid earning money if they are to have any longevity. Were the federal government given a free hand to tax the income of the religious organizations, it could tax them out of existence. It is hard to conceive of a greater intrusion on religious autonomy.

\section{A. Tax Policy Supports Treating Religious Tax Exemptions as \\ Constitutionally Required Rather than as Subsidies}

The Court's tendency to characterize religious tax exemptions as subsidies is rooted in what is called tax expenditure analysis. The central premise of this analysis is that tax provisions fall into one of two categories: one, normative provisions, which define the base of the tax; or two, expenditure provisions, which deviate from the base in a manner equivalent to direct government expenditures. ${ }^{185}$ A normative provision defines the tax base by spelling out the assets or income streams subject to taxation. ${ }^{186}$ The tax base of a property tax, for instance, is a list of the real propertywhether commercial, residential, or industrial-subject to the tax. An expenditure provision is any deviation from the defined tax base. ${ }^{187}$ So any deduction, exclusion, or exemption is a deviation from the base and therefore a tax expenditure, meaning it is the equivalent of a subsidy from the public fisc. It is as if the government made the decision to spend money directly in favor of whatever entity is the beneficiary of the deduction, exclusion, or exemption.

Consider Walz again. The base of the New York tax could be characterized as all real property in the state. The exemption of religious properties was a deviation from that base. ${ }^{188}$ So, under tax expenditure analysis, the exemption would be an expenditure-a decision by the state to subsidize religious organization. Or consider Texas Monthly. The base of the Texas tax was the sale of any periodical in the state. The exemption of religious periodicals was a deviation from that base. ${ }^{189}$ So, using tax expenditure analysis, the exemption was an expenditure-it constituted a subsidy of religious organizations publishing religious periodicals.

The rub with tax expenditure analysis is that it provides no rule of thumb for when to classify a particular tax provision as normative or as an

185 See Erika King, Tax Exemptions and the Establishment Clause, 49 SyRACuSE L. REv. 971, 994 (1999).

186 See Edward A. Zelinsky, James Madison and Public Choice at Gucci Gulch: A Procedural Defense of Tax Expenditures and Tax Institutions, 102 YALE L.J. 1165, 1168-71 (1993).

187 See id.

188 See Walz, 397 U.S. at 666-67.

189 See Texas Monthly, 489 U.S. at 5-7. 
expenditure. When is the government defining the base of a tax and when is it deviating from that base to subsidize a particular entity? Nothing compels the classification of a tax provision as one or the other. Yet that classification is essential for knowing when it is fair to treat a deduction, exclusion, or exemption as a government subsidy as opposed to merely defining the contours of a tax. ${ }^{190}$

With Walz, the religious tax exemption could just as easily be classified as normative as it could be as an expenditure. The base of the New York property tax could be viewed as "personal residences and business property." ${ }^{\prime 91}$ The exemption for religious or charitable properties then would be part of defining the tax base rather than an expenditure. If religious properties are not part of the base to begin with, then their exemption from the tax is not a deviation. And thus, under tax expenditure analysis, the exemption is not an expenditure and cannot be called a subsidy.

The Court has reflexively classified many religious tax exemptions as expenditure provisions. But nothing in tax expenditure analysis compels this conclusion. In fact, the Court's knee-jerk reaction to religious tax exemptions ignores the reality that much tax exemption is best understood as base defining. Take for example my own state of Florida. Florida is financed largely by a six percent sales tax. The state imposes no personal income tax. It is not compelling to characterize the state's failure to tax personal income as a "subsidy" of citizen's income. Rather, the state's taxing power excludes personal income as a matter of tax base selection.

The same can be said of religious tax exemptions. In Murdock and Follett, Justice Murphy noted that it was unconvincing to consider the Court's exemption of the Jehovah's Witnesses from the city's licensing tax as a subsidy, since the city could not tax them without running afoul of the First Amendment. ${ }^{192}$ If the Constitution mandates the exclusion of the Jehovah's Witnesses from the tax base to begin with, it is not a "subsidy" to refrain from taxing them. Rather, it is the implementation of a constitutionally-required tax base.

As pointed out above, the Court's concern about church and state separation has permeated its consideration of religious tax exemptions. That concern suggests that exemptions for religious organizations are normative rather than expenditures. The government is defining its tax base in recognition of the autonomy of religious organizations. It is not making a

190 See Zelinsky, supra note 25, at 809-10.

191 Boris I. Bittker, Churches, Taxes and the Constitution, 78 YALE L.J. 1285, 1291 (1969).

192 See Follett v. Town of McCormick, 321 U.S. 573, 579 (1944) (Murphy, J., concurring). 
decision to subsidize their message or mission.

McCulloch v. Maryland ${ }^{193}$ provides a parallel. The State of Maryland "impose[d] a tax on all banks or branches thereof, in the state of Maryland, not chartered by the legislature." 194 The state's tax base seemingly included the bank established by the federal government, since it was not chartered by the state legislature. As such, the Court's decision that the Constitution required the exemption of the federal bank from the tax could be viewed as a subsidy. The exemption was a deviation from the defined tax base. But that's not how the Court viewed its decision. Rather, the Court saw it as the implementation of a constitutionally required tax base. Federalism-the very structure of government established by the Constitution-placed the federal bank outside of Maryland's tax power. ${ }^{195}$ The state could not include the bank within its tax base to begin with, so the exemption of the federal bank could not be considered a subsidy.

The religious exemption from the federal income tax is similar. Much like federalism placed the federal bank beyond the taxing power of the State of Maryland, the Establishment Clause - and the ensuing concerns about religious autonomy-places religious organizations beyond the federal government's power to tax. The religious exemption in Section 501(c)(3) implements the constitutionally required tax base. It does not constitute an expenditure or subsidy in favor of religion. ${ }^{196}$

The Court cannot blithely label a religious tax exemption as a subsidy - a deviation from the tax base-unless there is agreement as to normative tax base to begin with. Nothing in tax expenditure analysis mandates that a religious tax exemption be denominated an expenditure provision rather than a normative provision. The Court's consistent concern for religious autonomy suggests religious tax exemptions are a proper acknowledgement of the sovereignty of religious institutions. As such, religious tax exemptions are not subsidies, because they implement, rather than deviate from, the normative tax base.

193 McCulloch v. Maryland, 17 U.S. 316 (1819).

194 Id. at 317.

195 See id. at 428

196 The Supreme Court itself classified a tax credit for tuition dollars spent at private religious schools as normative in Arizona Christian School Tuition Organization v. Winn, 563 U.S. 125 (2010). In Winn, the Court dismissed on standing grounds a taxpayer challenge under the Establishment Clause to a tax credit given for individuals who contributed money to a student tuition organization that in turn provided scholarships for students to attend private schools, including religious ones. The taxpayer plaintiffs argued that the tax credit was akin to a subsidy or governmental expenditure, which the taxpayers would have standing to challenge under the Establishment Clause. The Court disagreed, explaining that there is a difference between when the government spends money and "[w]hen the government declines to impose a tax." Id. The credit was part of defining the base of the tax rather than an expenditure. 
B. The History of Religious Tax Exemptions Reinforces Their Constitutional Necessity

Treating religious tax exemptions as constitutionally required explains the thoughts and actions of the founding generation. As Professor Zelinsky has aptly said, "Much ink has been spilled addressing the apparent paradox that the founding generation proclaimed the separation of church and state while simultaneously confirming and extending tax exemption for churches." ${ }^{\prime 197}$ The states ratified the Establishment Clause of the First Amendment, along with the rest of the Bill of Rights, in 1791. ${ }^{198}$ "Religious tax exemptions were not an issue in the petitions calling for the Bill of Rights, in the pertinent congressional debates, or in the debates preceding ratification by the states." 199 Yet that was not because they did not exist or could not be foreseen. In fact, religious tax exemptions "were widespread during colonial days. ${ }^{200}$ Rather, it is more likely that the founders simply viewed religious tax exemptions as consistent with separation. Or, more strongly put, that such exemptions actually furthered separation rather than contradicted it.

The Commonwealth of Virginia's story is illustrative of how the founders viewed the interplay of religious tax exemptions and church, state separation. ${ }^{201}$ Virginia established the Anglican Church as the state church in $1619 .^{202}$ And it continued as the state church until 1799, when the Virginia General Assembly passed the Act to Repeal Certain Acts, and to Declare the Construction of the Bill of Rights and Constitution, Concerning Religion. ${ }^{203}$ Although Thomas Jefferson's Bill for Establishing Religious Freedom from 1786 is often celebrated as the end to Virginia's official state church, the bill "did not expressly disestablish the Anglican Church (or its successor the Protestant Episcopal Church)." 204 "The church could, under the letter of [Jefferson's bill], continue to enjoy the imprimatur of the state

197 Zelinsky, supra note 25, at 839.

198 See Bill of Rights FAQs, NAT'L CONST. CTR., http://constitutioncenter.org/media/files/BORfaqs.pdf (last visited Nov. 7, 2015).

199 Walz v. Tax Comm'n of N.Y.C., 397 U.S. 664, 682 (1970) (Brennan, J., concurring).

200 Id.

201 The Supreme Court has repeatedly said, "The Commonwealth's efforts to separate church and state provided the direct antecedents of the First Amendment." McGowan v. Maryland, 366 U.S. 420, 437 (1961); Everson v. Bd. of Educ. of Ewing Twp., 330 U.S. 1, 33-38 (1947) (Rutledge, J., dissenting).

202 See A Documentary History of Religion In AMERICA to 1877, at 58 (Edwin S. Gaustad \& Mark A. Noll eds., 3d ed. 2003).

203 Walz, 397 U.S. at 683 (Brennan, J., concurring).

204 Carl H. Esbeck, Protestant Dissent and the Virginia Disestablishment, 1776-1786, 7 GEO. J. L. \& PUB. POL'Y 51, 88 (2009). 
(just not its financial support), as well as the state's preferential treatment." 205 The government could even continue to have a "hand in clerical appointments or the regulation of the liturgy." 206 It was not until thirteen years later, in 1799, that the Commonwealth officially disestablished the Anglican Church. ${ }^{207}$

The 1799 Act affirmed that the Virginia Bill of Rights had "excepted from the powers given to the government, the power of reviving any species of ecclesiastical or church government... by referring the subject of religion to conscience." 208 And going directly to disestablishment, the Act pronounced that the repealed measures that had "bestowed property upon the [Anglican Church]," had "asserted a legislative right to establish any religious sect," and had "incorporated religious sects," were "inconsistent with the principles of the constitution, and of religious freedom, and manifestly tends to the reestablishment of a national church." 209 Yet just one year after the passage of this Act, Virginia re-enacted a measure exempting from taxation property belonging to "any . . . college, houses for divine worship, or seminary of learning." 210 This exemption dated at least from 1777 and had been reaffirmed immediately before and after ratification of the First Amendment. ${ }^{211}$ Virginians, thus, did not view the exemption for "houses of divine worship" as somehow re-establishing religion. Religious tax exemption and separation could at least co-exist.

The best explanation of this tension between the founding generation simultaneously propounding separationism and religious exemptions is that they thought of exemptions as furthering church, state separation. It is only when religious tax exemptions are thought of as subsidies that the founding generation's actions seem illogical. How could they have pushed for the disestablishment of churches and at the same time pushed for the government to subsidize them? They could not and, in fact, did not. Their actions show that they understood religious exemptions as a proper recognition of religious autonomy and therefore, compatible with the separation of church and state.

$205 I d$

206 Id

207 See Michael V. Hernandez, A Flawed Foundation: Christianity's Loss of Preeminent Influence on American Law, 56 RUTGERS L. REV. 625, 657-58 (2004).

208 Walz, 397 U.S. at 683 (Brennan, J., concurring) (quoting 2 Va. Statutes at Large of 1792 1806 (Shepherd) 149).

209 Id.

210 Id.

211 Id. 


\section{THE EXCEPTIONAL CASE OF Bob JONES UNIVERSITY V. UNITED STATES}

The Supreme Court in Bob Jones treated the religious exemption in Section 501(c)(3) as being constitutionally compelled, rather than as a matter of government subsidy. Had the Bob Jones Court believed the exemption was a subsidy, then the Court need not have considered whether the "IRS construction of $\S 170$ and $\S 501(\mathrm{c})(3)$ violate[d] [the schools'] free exercise rights under the Religion Clauses of the First Amendment." ${ }^{212}$ As Professor Eugene Volokh has observed, "The government need not subsidize the exercise of constitutional rights. ${ }^{, 13}$ A subsidy is a matter of government largess. If the IRS determines that subsidizing racially discriminatory private schools is contrary to the policies it seeks to promote, then it can simply choose no longer to subsidize those schools.

But that is not what the Court did. The Court acknowledged that the "[d]enial of tax benefits will inevitably have a substantial impact on the operation of private religious schools." ${ }^{214}$ It carefully set churches and other religious institutions to one side, recognizing the heightened concerns about religious autonomy. ${ }^{215}$ "We deal here only with religious schools — not with churches or other purely religious institutions." ${ }^{216}$ Instead, the Court held that the government's interest in eradicating race discrimination in education was "so compelling as to... substantially outweigh[] whatever burden denial of tax benefits places on [the schools'] exercise of their religious beliefs." 217 According to the Court, "The interests [in religious autonomy] asserted by petitioners [Bob Jones University and Goldsboro Christian Schools] cannot be accommodated with that compelling governmental interest." 218

It was the government's unique and compelling "interest... in denying public support to racial discrimination in education" that justified the intrusion on religious autonomy. ${ }^{219}$ "[R]acially discriminatory schools exert a pervasive influence on the entire educational process," said the Court, "outweighing any public benefit that they might otherwise provide. ${ }^{, 220}$ The Court has recognized no similar interest when it comes to

212 Bob Jones Univ. v. United States, 461 U.S. 574, 603 (1983).

213 Eugene Volokh, Freedom of Expressive Association and Government Subsidies, 58 STAN. L. REV. 1919, 1924 (2006).

214 Bob Jones, 461 U.S. at 603-04.

215 See id. at 604 n.29.

$216 I d$. (emphasis in original).

217 Id. at $603-04$.

218 Id. at 604.

219 Id. at 604 n.29.

$220 \quad I d$. 
private religious schools adhering to the view that marriage is the union of one man and one woman.

\section{A. The Run Up to Bob Jones}

The controversy in Bob Jones is rooted in the efforts of civil rights groups to curb the growth of racially discriminatory private schools. The U.S. Supreme Court declared racial segregation in public schools to be unconstitutional in Brown v. Board of Education ${ }^{221}$ in 1954. In the aftermath of Brown, thousands of white children in the South fled the newly integrated public schools. ${ }^{222}$ They sought refuge in private schools where they could continue to receive a segregated education. "In some communities, the white student body," according to Professor Olatunde Johnson, "moved en masse to a new private school, taking the indicia of the old schools, such as the school colors, symbols, and mascots."223 Many Southern state governments even encouraged the creation of these segregated, private schools by "enacting legislation mandating or allowing the closing of public schools to resist desegregation or providing state tax credits and tuition grants to students attending private schools." 224

Ten years after Brown, Congress passed the Civil Rights Act of $1964 .{ }^{225}$ Title VI of the Act specifically prohibited racial segregation and discrimination in schools that received "federal financial assistance.",226 Congress premised Title VI on the belief that federal dollars should not subsidize segregation in public schools. ${ }^{227}$ But rather than putting an end to the segregated education that dominated the South, Title VI resulted in even greater growth of private, segregated schools. ${ }^{228}$ One hundred and sixtyeight private schools opened in Mississippi, Alabama, Florida, Louisiana, North Carolina, and South Carolina between 1964 and 1967. Most were openly segregationist and operated by secular organizations. White citizens' councils, for instance, operated more than 150 all-white "segregation academies" in the South, serving more than 9,000 students. ${ }^{229}$

As time went by, more and more of these segregated, private schools were opened by Evangelical Christian churches. Indeed, by 1970, Christian

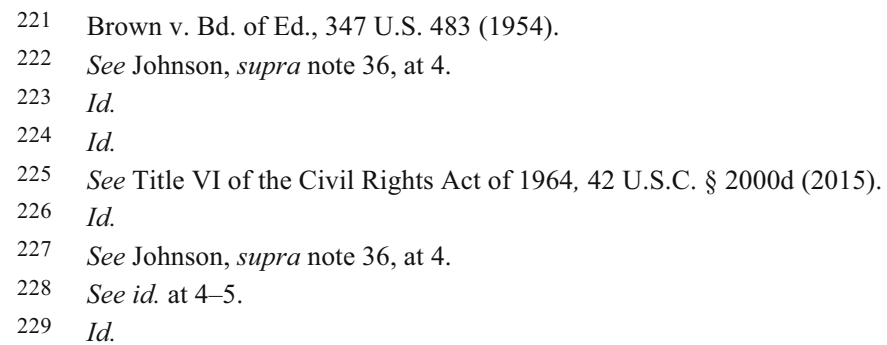


private schools outnumbered the secular schools. ${ }^{230}$ Many claimed that "Christian schools and segregation academies [were] almost synonymous." 231

When Congress passed Title VI, the Internal Revenue Service put a freeze on "applications for tax exemption under $\S 501$ (c)(3) of the [Internal Revenue] Code filed by private schools apparently found to be operated on a segregated basis." 232 The freeze was supposed to give the IRS time to consider whether tax exemptions qualified as "federal financial assistance" under Title VI. The freeze lasted two years. At the conclusion, the IRS issued a revenue ruling determining that private, segregated schools could only be denied tax-exempt status where "[s]tate action for constitutional purposes" was found. ${ }^{233}$ Because government assistance-whether tax exemptions or otherwise-does not generally convert private action into "state action," the revenue ruling effectively shielded the schools from losing their tax exemptions. ${ }^{234}$ Indeed, the very same day the IRS issued its ruling, it approved tax-exempt status for more than forty segregated, private schools. $^{235}$

The IRS's ruling did not sit well with civil rights groups. The Lawyers Committee for Civil Rights Under Law (LCCR) orchestrated a lawsuit, ultimately known as Green v. Connally, "to enjoin the Secretary of the Treasury from granting tax-exempt status to private schools in Mississippi which discriminate[d] against Negroes in admissions." ${ }^{236}$ LCCR argued that the IRS's ruling violated constitutional and statutory prohibitions on government aid to racially discriminatory organizations. ${ }^{237}$ A three-judge district court agreed and preliminarily enjoined the IRS "from issuing

$230 \quad I d$.

231 Joseph Crespino, Civil Rights and the Religious Right, in RIGHTWARD BOUND: MAKING AMERICA CONSERVATIVE IN THE 1970S 96 (Bruce Schulman \& Julian E. Zelizer eds., 2008).

232 Green v. Kennedy, 309 F. Supp. 1127, 1130 (D.D.C. 1970)

233 The IRS's ruling provided as follows:

The Service stated that its general conclusion is that exemption will be denied and contributions will not be deductible if the operation of the school is on a segregated basis and its involvement with the state or political subdivision is such as to make the operation unconstitutional or a violation of the laws of the United States.

Where, however, the school is private and does not have such degree of involvement with the political subdivision as has been determined by the courts to constitute State action for constitutional purposes, rulings will be issued holding the school exempt and the contributions to it deductible assuming that all other requirements of the statute are met.

Press Release, Internal Revenue Service (Aug. 2, 1967), 1967 CCH STANDARD FED. TAX REP. ๆ 6734.

234 See, e.g., Rendell-Baker v. Kohn, 457 U.S. 830 (1982); Blum v. Yaretsky, 457 U.S. 991

(1982).

235 See Kennedy, 309 F. Supp. at 1131.

236 Id. at 1129.

237 See id. at 1129-30. 
further ruling letters under sections $170(\mathrm{c})$ and $501(\mathrm{c})$ of the Internal Revenue Code to private schools in Mississippi."238

In response to the ruling, the IRS concluded that it could "no longer legally justify allowing tax-exempt status [under $\S 501(\mathrm{c})(3)$ of the Internal Revenue Code] to private schools which practice racial discrimination.,"239 At the same time, the IRS announced that it would no longer "treat gifts to such schools as charitable deductions for income tax purposes [under $\S$ 170]." ${ }^{240}$ A few months later, the IRS formally notified private schools of its change in policy. ${ }^{241}$

The Green court eventually issued its opinion on the merits, approving the IRS's new construction of its code. ${ }^{242}$ The three-judge district court held that "racially discriminatory private schools were not entitled to exemption under $\S 501(\mathrm{c})(3)$ and that donors were not entitled to deductions for contributions to such schools under $\S 170 .{ }^{243}$ The court reasoned that segregated private schools were not "charitable" within the meaning of the law because they operated contrary to federal public policy against racial discrimination. The court, thus, permanently enjoined the Commissioner of the Internal Revenue from approving tax-exempt status for any school in Mississippi that did not publicly maintain a policy of nondiscrimination. ${ }^{244}$

A group of parents supporting tax exemptions for segregated schools appealed the case directly to the U.S. Supreme Court. The Court summarily affirmed the district court's decision. ${ }^{245}$

A few months later, the IRS issued a revenue ruling formalizing its new policy on the tax-exempt status of racially discriminatory private schools. ${ }^{246}$ Private schools that discriminated on the basis of admission in the administration of educational and other school-administered programs could not be considered charitable within the meaning of sections 501(c)(3) or $170(\mathrm{a}){ }^{247}$ Both provisions incorporated common-law notions that charitable trusts could not be illegal or contrary to public policy. While private discrimination in schools was not illegal, "federal policy against

238 Id. at 1131.

239 Bob Jones Univ. v. United States, 461 U.S. 574, 578 (1983) (quoting I.R.S. News Release (July 10, 1970), reprinted in 7 Stand. Fed. Tax Rep. (CCH) 6,790).

$240 \mathrm{Id}$

241 See id.

242 See Green v. Connally, 330 F. Supp. 1150, 1179 (D.D.C. 1971), aff'd sub nom. Coit v. Green, 404 U.S. 997 (1971).

243 Bob Jones, 461 U.S. at 578; see also Connally, 330 F. Supp. at 1155.

244 See Connally, 330 F. Supp. at 1164.

245 See Coit, 404 U.S. at 997.

246 See Rev. Rul. 71-447, 1971-2 C.B. 230.

247 See id. 
racial discrimination is well-settled," as reflected in judicial pronouncements such as Brown and Title VI. ${ }^{248}$

\section{B. The IRS Denies Tax-Exempt Status to Bob Jones University and Goldsboro Christian Schools}

Bob Jones University and Goldsboro Christian Schools were among the private schools the IRS notified following the preliminary injunction in Green v. Kennedy that their racially discriminatory practices jeopardized their tax-exempt status. ${ }^{249}$ Goldsboro flatly denied admission to black students, while Bob Jones admitted black students but prohibited interracial dating and marriage. Both schools genuinely believed that the Bible forbade "racial intermixing." 250 When the schools failed to comply with the IRS's demands, the IRS revoked their tax-exempt status.

That presented a problem for the schools. Being tax exempt under Section 501(c)(3) allowed the schools to avoid federal income taxation, meaning the difference between their revenues, like donations and tuition, and their expenses, like wages and maintenance costs, were not treated as taxable income. Now the schools had to pay tax on this income. Moreover, donors to Bob Jones and Goldsboro could no longer deduct donations to the schools from their taxes. That obviously made donating to the schools less attractive. $^{251}$ The schools sued in federal court, advancing two primary arguments: first, the IRS exceeded its authority when it interpreted Section 501(c)(3) to exclude racially discriminatory schools and, second, the revocation of tax exemption intruded on their religious autonomy protected by the religious clauses of the First Amendment. ${ }^{252}$

The Court was not sympathetic to either of the schools' arguments. The IRS's interpretation of Section 501(c)(3), and its subsequent application to the schools, comported with historic notions of what constituted a charity. The Court found that "§ 170 and $\S 501(c)(3)$ embrace[d] the common law 'charity' concept." ${ }^{, 53}$ That concept, according to the Court, included "the requirement, long recognized in the law of trusts, that the purpose of a charitable trust may not be illegal or violate established public policy." 254 One such "established public policy" in the United States was "that racial discrimination in education violates deeply

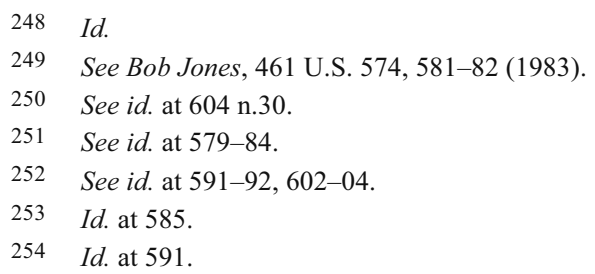


and widely accepted views of elementary justice."255 "Over the past quarter of a century, every pronouncement of this Court and myriad Acts of Congress and Executive Orders," said the Court, "attest a firm national policy to prohibit racial segregation and discrimination in public education." 256 Were the IRS to give tax-exempt status to Bob Jones and Goldsboro, it would plainly run afoul of this well established public policy. "It would be wholly incompatible with the concepts underlying tax exemption," said the Court, "to grant the benefit of tax-exempt status to racially discriminatory educational entities." 257

The Court acknowledged that the denial of the schools' tax-exempt status had a "substantial impact" on their religious autonomy, but said that the government "may justify a limitation on religious liberty by showing that it is essential to accomplish an overriding governmental interest."258 "[T]he Government," said the Court, "has a fundamental, overriding interest in eradicating racial discrimination in education." 259 Whatever the intrusion on the schools" religious autonomy, it was "substantially outweigh[ed]" by the government's interest in rooting out race discrimination in education. ${ }^{260}$ The Court, thus, upheld the denial of tax-exempt status to both schools.

\section{The Limited Reach of the Court's Decision}

In reaching its conclusion in Bob Jones, the Court acknowledged the sensitivity with which public policy matters are imbued.

We are bound to approach these questions with full awareness that determinations of public benefit and public policy are sensitive matters with serious implications for the institutions affected; a declaration that a given institution is not "charitable" should be made only where there can be no doubt that the activity involved is contrary to a fundamental public policy. ${ }^{261}$

The Court underscored the limited circumstances in which the IRS and the courts may even consider the effect of public policy. "We emphasize," said the Court, "that these sensitive determinations should be made only where there is no doubt that the organization's activities violate fundamental

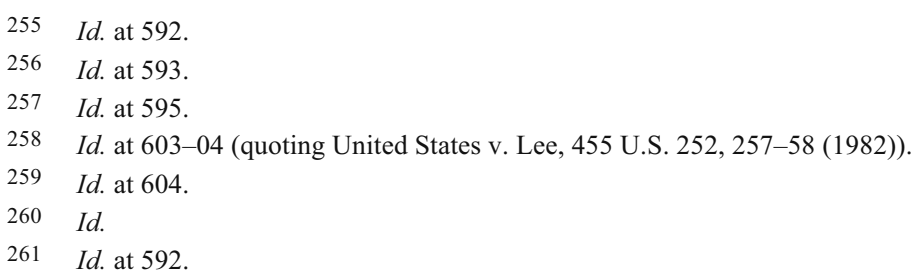


public policy."262 The Court expressly left open "whether an organization providing a public benefit and otherwise meeting the requirements of $\S$ 501(c)(3) could nevertheless be denied tax-exempt status if certain of its activities violated a law or public policy."263

The Bob Jones Court itself limited its ruling to "religious schools" and only when "the governmental interest is in denying public support to racial discrimination in education." ${ }^{264}$ It is not at all clear that the Court intended to create a free-floating public policy doctrine, whereby the IRS can deny tax-exempt status anytime it determines an organization's actions or beliefs violate public policy. Professor Douglas Kmiec points out, "[T]here have been very few true extensions of the Bob Jones public policy limitation outside the racial discrimination context." 265

Only a handful of court decisions have done more than mention the public policy limitation from Bob Jones in passing. ${ }^{266}$ Of those, only two merit comment. First, in Church of Scientology v. Commissioner of Internal Revenue, ${ }^{267}$ the United States Tax Court upheld the IRS's revocation of income tax exemption of the Church of Scientology. But the organization's activities were clearly illegal. The Church "impede[d] the IRS in performing its duty to determine and collect taxes from petitioner and other Scientology churches." 268 The activities alleged were egregious"petitioner filed false tax returns, burglarized IRS offices, stole IRS documents, and harassed, delayed, and obstructed IRS agents who tried to audit the Church's records. ${ }^{, 269}$

Second, in Synanon Church v. United States, ${ }^{270}$ a federal district court in the District of Columbia ruled that Synanon failed to establish entitlement to exemption under Section 501(c)(3). Synanon was allegedly founded to rehabilitate drug addicts and to engage in related research and public education. However, the organization regularly "advocate[d] terror

262 Id. at 598.

263 Id. at 596 n.21.

264 Id. at 604 n.29.

265 Douglas W. Kmiec, Same-Sex Marriage and the Coming Antidiscrimination Campaigns Against Religion, in SAME-SEX MARriage And Religious LiberTy: EMERGING Conflicts 103, 109 (Douglas Laycock, Anthony R. Picarello, Jr. \& Robin Fretwell Wilson eds., 2008).

266 See Jerry Rex Buckles, Reforming the Public Policy Doctrine, 53 U. KAN. L. REV. 397, 403 (2005) ("Judicial decisions following Bob Jones add little to the doctrine espoused by the Supreme Court. Few decisions have done more than mention the public policy doctrine in passing.").

26783 T.C. 381 (1984), aff'd, 823 F.2d 1310 (9th Cir. 1987).

268 Id. at 503.

269 Id. at 505.

270579 F. Supp. 967 (1984), aff'd, 820 F.2d 421 (D.C. Cir. 1987). 
and violence." 271 The district court found "repeated attacks and threats of violence committed by Synanon members against those perceived as enemies of the organization." ${ }^{272}$ But the court ultimately based its denial of the tax exemption on the organization's "systematic destruction of tapes and alteration of records... contemporaneous with an IRS audit." 273 Despite Synanon's illegal behavior, the court declined to rely on the public policy doctrine from Bob Jones as the basis for decision. The court said, "[It was] concerned with the proper application of the Bob Jones analysis if it could be said that Synanon conferred some arguable public benefit-drug rehabilitation, for example-while simultaneously maintaining a policy of violence and terror." 274

Outside the courts, Bob Jones has been administratively extended to include racial discrimination in any 501(c)(3) context. For instance, the IRS considered a tax exemption for a charitable trust that provided "for the benefit and relief of worth and deserving white persons." 275 The trust furnished goods and services to needy, Caucasian citizens over the age of sixty. ${ }^{276}$ The IRS said that the Bob Jones decision "leaves little doubt" that racial discrimination, "whether in an educational context or otherwise," violates public policy in such a fundamental way as to justify revocation of an entity's tax-exempt status. ${ }^{277}$ The trust's racially restrictive provision, according to the IRS, "foster[ed] racial discrimination" and, therefore, was contrary to "clearly defined federal public policy against racial discrimination." 278

In a private letter ruling in 1988, the IRS likewise said, "Although applying on its face only to race discrimination in education, the implication of the Bob Jones decision extends to any organization claiming exempt status under Section 501(c)(3) and to activity violating a clear public policy." ${ }^{279}$ The letter ruling concerned a privately administered trust that restricted beneficiaries to "worthy and deserving white persons." 280 The IRS held that the trust did not qualify for tax exemption under Section 501(c)(3) since it "aggravate[d] the burdens placed on those who have traditionally been the subject of discrimination and thereby fosters racial

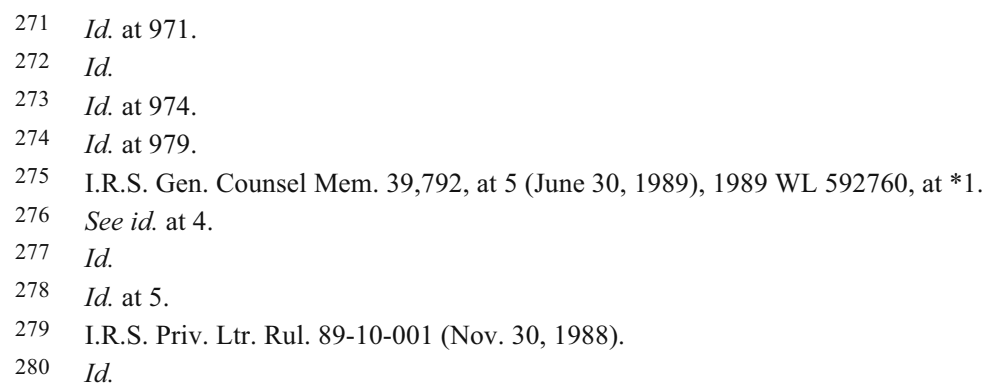


discrimination. ${ }^{281}$ Consequently, the trust's activities were "contrary to a clearly defined public policy" against racial discrimination. ${ }^{282}$

But the IRS has refused to push Bob Jones beyond the topic of race. For example, when a support program for teaching the literature and history of the Bible was challenged as violating the Establishment Clause, ${ }^{283}$ the IRS determined that "the objection was without merit." ${ }^{284}$ It cautioned against "finding Bob Jones like violations of public policy premised on other individual rights." 285 The IRS noted that it could "think of no more fundamental federal public policy than the Bill of Rights." ${ }^{286}$ More recently, the IRS refused to revoke an exemption on public policy grounds for an over accumulation of income. The IRS commented that "[c]urrently the sole basis for revocation of exemption on public policy grounds is engaging in racial discrimination., 287

The reluctance of the courts and the IRS to expand Bob Jones beyond racial discrimination makes sense. Professor Johnny Rex Buckles has rightly said that an expansion of "[t]he public policy doctrine presents a thorny array of other concerns," 288 including most basically: what defines the contours of public policy; what makes public policy fundamental; what role, if any, does state law play in defining public policy; and how many acts would demonstrate a disregard of public policy? These questions have no clear answers.

All these considerations point to what Professor Olatunde Johnson observed about Bob Jones. The case is "too extraordinary to matter much." ${ }^{289}$ It sits alongside Supreme Court cases like Brown v. Board of Education $^{290}$ and Heart of Atlanta Motel v. United States, ${ }^{291}$ where the Court undertook extraordinary measures to remedy the evil of race discrimination. The cases are important victories for civil rights but they do

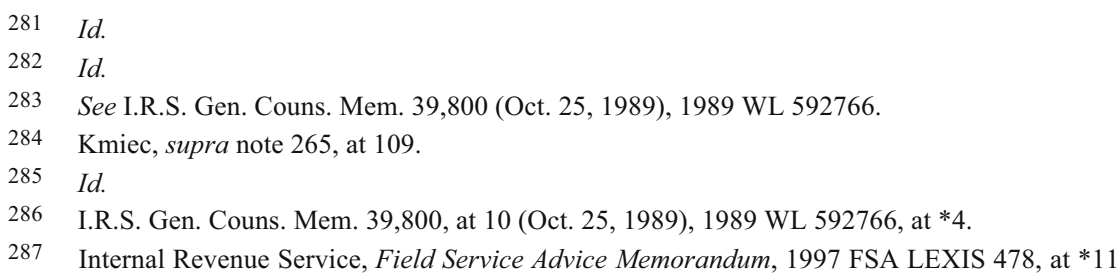
(Apr. 23, 1997).

288 Buckles, supra note 266, at 398.

289 Johnson, supra note 36, at 29; see also James A. Davids, Enforcing a Traditional Moral Code Does Not Trigger a Religious Institution's Loss of Tax Exemption, 24 REgENT U. L. REV. 433, 435 (2012) ("[A]fter reviewing the context of the Bob Jones case ... it is little wonder [that] neither the Internal Revenue Service... nor the Supreme Court has extended the sanction beyond private educational institutions that discriminate on the basis of race.").

290347 U.S. 483 (1954).

291379 U.S. 241 (1964). 
not establish broad rules that can be applied outside the context of eradicating racism. In short, Bob Jones and its ilk are, as Professor Michael Paulsen has said, "sui generis.",292

\section{BOB JONES DOES NOT JUSTIFY STRIPPING RELIGIOUS ORGANIZATIONS OF THEIR TAX-EXEMPT STATUS BECAUSE OF THEIR VIEWS ON MARRIAGE}

The Bob Jones Court recognized the importance of protecting the autonomy of religious organizations but ruled that the government's interest in eradicating race discrimination in education was so "fundamental" and "overriding" to justify abrogating the wall between church and state. ${ }^{293}$ When it comes to same-sex marriage, there is no similarly "fundamental" and "overriding" interest that warrants ignoring the protections for religion provided by the Establishment Clause.

The "fundamental" and "overriding" interest in Bob Jones was specific as to education. ${ }^{294}$ Nine times the majority emphasized that "racial discrimination in education violates a fundamental public policy." 295 The federal government's condemnation of racial discrimination in education "was unmistakably clear." 296 "Over the past quarter of a century, every pronouncement of this Court and myriad Acts of Congress and Executive Orders," said the Court, "attest a firm national policy to prohibit racial

292 Paulsen, supra note 42, at 694.

293 Bob Jones Univ. v. United States, 461 U.S. 574, 604 (1983).

294 Id. ("[T]he Government has a fundamental, overriding interest in eradicating racial discrimination in education.") (emphasis added).

295 Id. at 594 (emphasis added); see also id. at 579 ("Based on the national policy to discourage racial discrimination in education, the IRS ruled that a private school not having a racially nondiscriminatory policy as to students is not 'charitable' within the common law concepts reflected in sections 170 and 501(c)(3) of the Code.") (emphasis added); id. at 582 (Bob Jones University's "racial policies violated the clearly defined public policy, rooted in our Constitution, condemning racial discrimination and, more specifically, the government policy against subsidizing racial discrimination in education, public or private.") (emphasis added); id. at 592 ("But there can no longer be any doubt that racial discrimination in education violates deeply and widely accepted views of elementary justice.") (emphasis added); id. at 593 ("An unbroken line of cases following Brown v. Board of Education establishes beyond doubt this Court's view that racial discrimination in education violates a most fundamental national public policy, as well as rights of individuals.") (emphasis added); id. at 595 ("Whatever may be the rationale for such private schools' policies, and however sincere the rationale may be, racial discrimination in education is contrary to public policy.") (emphasis added); id. at 604 ("the Government has a fundamental, overriding interest in eradicating racial discrimination in education") (emphasis added); id. at 584 n.23 ("if any national policy is sufficiently fundamental to constitute such an overriding limitation on the availability of tax-exempt status under $\S 501(\mathrm{c})(3)$, it is the policy against racial discrimination in education") (emphasis added); id. at $604 \mathrm{n} .29$ ("We deal here only with religious schools - not with churches or other purely religious institutions; here, the governmental interest is in denying public support to racial discrimination in education.") (emphasis added).

296 Id. at 598. 
segregation and discrimination in public education."297 No similar unanimity exists within the three branches of the federal government with regard to sexual orientation discrimination in education.

The educational context of Bob Jones shows that the private religious schools arose, particularly in the South, as a way to avoid desegregation. Jim Crow laws formalized school segregation in $1877 .^{298}$ That segregation continued until 1954 with the Supreme Court's decision in Brown v. Board of Education, ${ }^{299}$ which mandated racially-integrated schools. Brown put an end to the formal, legal segregation that had lasted 77 years. In response, as explained above, a slew of private religious schools cropped up as an end run of racial integration. Many of these private schools had state support. In Bob Jones, the Supreme Court closed the loophole. It finally put the kibosh on attempts to dodge the racial integration required by Brown.

Gays and lesbians have faced no similar history of discrimination in education. Private religious schools, like Wheaton College ${ }^{300}$ and Biola University, ${ }^{301}$ did not spring up to provide avenues for students to avoid gays and lesbians. Indeed, the educational environment for gays and lesbians is mostly favorable. Many colleges and universities undertake "special recruiting efforts for gay students." 302 Organizations, like Campus Pride, hold college fairs across the country catering to gays and lesbians. ${ }^{303}$ "Ivy League schools are often represented" at these fairs, according to the New York Times. ${ }^{304}$ Schools like Duke University and the Massachusetts Institute of Technology specifically ask applicants about sexual orientation on their admissions application. ${ }^{305}$ University officials refer to gays as "the new blue-chip recruits." ${ }^{306}$ That hardly seems the kind of treatment calling for the extraordinary measures employed by the Court in Bob Jones.

No laws have been passed barring schools from discriminating on the basis of sexual orientation. Title IX of the Education Amendments of 1972 does not prohibit "harassment or discrimination based upon sexual

297 Id. at 593.

298 See William M. Wiecek \& Judy L. Hamilton, Beyond the Civil Rights Act of 1964: Confronting Structural Racism in the Workplace, 74 LA. L. REV. 1095, 1099 (2014) (discussing "the comprehensive racial regime that we know as segregation or Jim Crow, which lasted from the end of Reconstruction in 1877 until it began to crumble in the Second Reconstruction after 1954").

299347 U.S. 483 (1954).

300 See Wheaton College, www.wheaton.edu (last visited Sept. 10, 2015).

301 See Biola University, www.biola.edu (last visited Sept. 10, 2015).

302 See Schwartz, supra note 43.

303 See CAMPUS PRIDE, www.campuspride.org (last visited Sept. 10, 2015).

304 Schwartz, supra note 43; see also Shafrir, supra note 43.

305 See Jaschik, supra note 43.

306 See Lamb, supra note 43. 
orientation." ${ }^{307}$ The U.S. Department of Education suggested last year that perhaps "Title IX's sex discrimination prohibition extends to claims of discrimination based on gender identity or failure to conform to stereotypical notions of masculinity or femininity." ${ }^{308}$ But Congress has taken no action to expand the reach of Title IX.

Outside the context of education, the federal government has still been largely silent on sexual orientation discrimination. Presidents Clinton and Obama signed executive orders prohibiting sexual orientation discrimination by the federal government and its contractors. ${ }^{309}$ But federal law otherwise does not prohibit sexual orientation discrimination. Congress has yet to pass the Employment Non-Discrimination Act (ENDA), which would ban discrimination on the basis of sexual orientation in employment nationwide. ENDA has been introduced in every Congress since 1994, but has yet to pass both houses. The Senate, but not the House, passed a version of ENDA in November 2013. The Senate included a broad exemption for religious organizations, including private religious schools. ${ }^{310}$

Obergefell did nothing to change the calculus. The Obergefell court largely rooted its decision in the fundamental right to marry. It acknowledged that "the right of same-sex couples to marry that is part of the liberty promised by the Fourteenth Amendment is derived, too, from that Amendment's guarantee of the equal protection of the laws." ${ }^{311}$ But it did not hold that sexual orientation is a suspect or quasi-suspect classification. Obergefell is strictly about marriage, not about prohibiting discrimination more broadly against gays and lesbians.

The current state of federal law does not seem to provide the kind of "fundamental" and "overriding" interest sufficient to set aside the Constitution's mandate of church, state separation. In Bob Jones, there was a "firm national policy to prohibit racial segregation and discrimination in public education." 312 The Court had no "doubt that racial discrimination in education violates deeply and widely accepted views of elementary justice." "313 The federal government had engaged in "consistent" efforts to eliminate racial discrimination in education - even by military force. There

307 Tyrrell v. Union Free Sch. Dist., 792 F. Supp. 2d 601, 622-23 (E.D.N.Y. 2011).

308 Emma Margolin, Transgender Students Protected Under Title IX, DOE Says, MSNBC (Apr. 30, 2014, 4:09 PM), www.msnbc.com/msnbc/transgender-students-protected-under-title-ix.

309 See Exec. Order No. 12,968, 60 Fed. Reg. 40245 (Aug. 2, 1995); Exec. Order No. 13,087, 63 Fed. Reg. 30097 (May 28, 1998); Exec. Order No. 13,672, 79 Fed. Reg. 42971 (July 21, 2014).

310 See Employment Non-Discrimination Act, WIKIPEDIA, http://en.wikipedia.org/wiki/Employ ment_Non-Discrimination_Act\#113th_Congress (last visited Sept. 9, 2015).

311 Obergefell v. Hodges, 135 S. Ct. 2584, 2602-03 (2015).

312 Bob Jones Univ. v. United States, 461 U.S. 574, 593 (1983).

313 Id. at 592. 
is no counterpart with sexual orientation discrimination. ${ }^{314}$

Of course that could change. Just this past summer, the EEOC interpreted Title VII of the 1964 Civil Rights Act to forbid sexual orientation discrimination on the job as a form of "sex" discrimination. ${ }^{315}$ The EEOC's views on the scope of Title VII are merely persuasive. Indeed, no court is required to follow the agency. Nonetheless, the EEOC's decision points to a possible shift in federal nondiscrimination law. If, and when, that shift occurs, the argument for a "fundamental" and "overriding" interest perhaps becomes a bit easier. But until that day comes, the autonomy of religious organizations, and the ensuing tax exemption under Section 501(c)(3), seem safe.

\section{CONCLUSION}

The calls from scholars and commentators to strip private religious schools of their tax-exempt status in the wake of Obergefell are off base. These calls have uniformly assumed that a tax exemption is a government subsidy. But when the federal government exempts religious organizations from paying income tax, it is not choosing to back religion. Rather, the government is recognizing that the Establishment Clause of the First Amendment mandates a separation of church and state. It imposes a structural restraint that places religious organizations beyond the taxing power of the federal government.

Bob Jones is an anomaly. Eradicating race discrimination in education is the only public policy the Court has held so "fundamental" and "overriding" to abrogate the autonomy of religious schools. The factual context of Bob Jones is so unique and extraordinary that, as Professor James Davids observed, "it is little wonder why neither the Internal Revenue Service... nor the Supreme Court has extended the sanction beyond private educational institutions that discriminate on the basis of race. ${ }^{316}$

No similar context exists for sexual orientation discrimination in education. If anything, gays and lesbians are sought after and welcomed by the most prestigious and powerful education institutions in the country.

\section{See id. at 594.}

315 See Complainant v. Foxx, EEOC Appeal No. 0120133080 (July 16, 2015), www. americanbar.org/content/dam/aba/administrative/sexual_orientation/eeoc-lgbt-title-vii-decision.authchec kdam.pdf.

316 James A. Davids, Enforcing a Traditional Moral Code Does Not Trigger a Religious Institution's Loss of Tax Exemption, 24 REGENT U. L. REV. 433, 435 (2012); see also id. at 455 ("[G]iven the extraordinary history and context of racial segregation in education, the likelihood of the Court finding a similar compelling interest in areas other than racial discrimination is remote."). 
People of faith did not establish private religious schools to evade gays and lesbians. The Establishment Clause protects the autonomy of these schools. It precludes the government from being handed the power to tax them out of existence. To paraphrase Professor Zelinksy, in the final analysis, tax exemption does not subsidize these religious schools, it leaves them alone. ${ }^{317}$ 